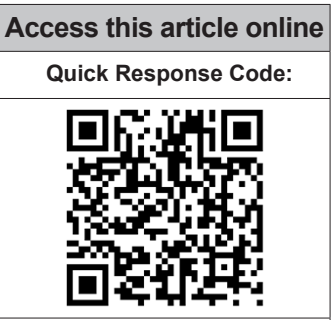

Website:

http://www.braincirculation.org

DOI:

10.4103/bc.bc_27_16
${ }^{1}$ Department of

Neurosurgery, Virginia

Commonwealth

University, Richmond,

VA, ${ }^{2}$ Department of

Neurosurgery, University

of South Florida College

of Medicine, Tampa,

FL, ${ }^{3}$ Department of

Pharmacotherapy

and Outcomes

Sciences, Laboratory of

Pharmacometabolomics

and Companion

Diagnostics, Virginia

Commonwealth University,

Richmond, VA, ${ }^{4}$ Banyan

Biomarkers, Inc., Alachua,

32615, ${ }^{5}$ Single Breath,

Inc., Gainesville, FL, USA

Address for correspondence:

Ms. Olena Y Glushakova,

Department of

Neurosurgery, Virginia

Commonwealth University

School of Medicine,

Richmond, Virginia, USA.

E-mail: olenaglushakova@

gmail.com,

Dr. Alexander V Glushakov,

Single Breath, Inc.,

Gainesville, FL, USA.

E-mail: glushakov@single-

breath.com

Submission: 15-12-2016

Revised: 10-04-2017

Accepted: 17-04-2017

\title{
Prospective clinical biomarkers of
} caspase-mediated apoptosis associated with neuronal and neurovascular damage following stroke and other severe brain injuries: Implications for chronic neurodegeneration

\author{
Olena Y Glushakova ${ }^{1}$, Andriy A Glushakov², Dayanjan S Wijesinghe ${ }^{3}$, Alex B Valadka', \\ Ronald L Hayes ${ }^{1,4}$, Alexander V Glushakov ${ }^{5}$
}

Abstract:

Acute brain injuries, including ischemic and hemorrhagic stroke, as well as traumatic brain injury (TBI), are major worldwide health concerns with very limited options for effective diagnosis and treatment. Stroke and TBI pose an increased risk for the development of chronic neurodegenerative diseases, notably chronic traumatic encephalopathy, Alzheimer's disease, and Parkinson's disease. The existence of premorbid neurodegenerative diseases can exacerbate the severity and prognosis of acute brain injuries. Apoptosis involving caspase-3 is one of the most common mechanisms involved in the etiopathology of both acute and chronic neurological and neurodegenerative diseases, suggesting a relationship between these disorders. Over the past two decades, several clinical biomarkers of apoptosis have been identified in cerebrospinal fluid and peripheral blood following ischemic stroke, intracerebral and subarachnoid hemorrhage, and TBI. These biomarkers include selected caspases, notably caspase- 3 and its specific cleavage products such as caspase-cleaved cytokeratin-18, caspase-cleaved tau, and a caspase-specific $120 \mathrm{kDa} \alpha$ ll-spectrin breakdown product. The levels of these biomarkers might be a valuable tool for the identification of pathological pathways such as apoptosis and inflammation involved in injury progression, assessment of injury severity, and prediction of clinical outcomes. This review focuses on clinical studies involving biomarkers of caspase-3-mediated pathways, following stroke and TBI. The review further examines their prospective diagnostic utility, as well as clinical utility for improved personalized treatment of stroke and TBI patients and the development of prophylactic treatment chronic neurodegenerative disease.

Keywords:

Caspase-3, caspase-cleaved cytokeratin-18, caspase-cleaved tau, stroke, traumatic brain injury, all-spectrin breakdown products

\section{Introduction}

A cute brain injuries such as stroke and traumatic brain injury (TBI) are a global health problem with very limited treatment options. An estimated 15 million people sustain stroke and 10 million people sustain TBI annually worldwide. ${ }^{[1-7]}$ In the United

This is an open access article distributed under the terms of the Creative Commons Attribution-NonCommercial-ShareAlike 3.0 License, which allows others to remix, tweak, and build upon the work non-commercially, as long as the author is credited and the new creations are licensed under the identical terms.

For reprints contact: reprints@medknow.com
States alone, approximately 1.5 million people are affected by TBI and over 700,000 people are affected by stroke annually, with an estimated mortality and long-term disability rate of over 50,000 and 90,000 persons per year from TBI. ${ }^{[8-14]}$ An estimated 130,000 Americans die from stroke annually. ${ }^{[2-4]}$

How to cite this article: Glushakova OY, Glushakov AA, Wijesinghe DS, Valadka AB, Hayes RL, Glushakov AV. Prospective clinical biomarkers of caspase-mediated apoptosis associated with neuronal and neurovascular damage following stroke and other severe brain injuries: Implications for chronic neurodegeneration. Brain Circ 2017;3:87-108. 
Stroke is classified into two main types: ischemic stroke and hemorrhagic stroke, including intracerebral hemorrhage and subarachnoid hemorrhage (SAH). ${ }^{[15-17]}$ Although ischemic stroke accounts for over $85 \%$ of all stroke cases, hemorrhagic stroke also imposes a comparable health burden. ${ }^{[18,19]} \mathrm{TBI}$ and stroke share several common features such as cerebral ischemia, excitotoxicity, and neuroinflammation, suggesting the presence of similar molecular mechanisms in the etiopathology of these disorders. For example, a postmortem study in TBI patients suggested that intracerebral hemorrhage is a common feature of severe TBI and secondary cerebral ischemia is a major factor associated with the most severely impaired outcomes after TBI. ${ }^{[13]}$ Moreover, TBI and stroke are major risk factors in the development of chronic neurodegenerative disorders and diseases such as posttraumatic and poststroke epilepsies, ${ }^{[20]}$ chronic traumatic encephalopathy (CTE) ${ }^{[21]}$ as well as Alzheimer's and Parkinson's diseases (AD and PD, respectively). ${ }^{[22-25]}$ Recent prospective clinical studies have shown that cerebral ischemia is a frequent comorbid condition of $\mathrm{AD}$ with the presence of cerebrovascular pathology in up to $84 \%$ of $\mathrm{AD}$ patients ${ }^{[26-28]}$ and stroke survivors also have elevated incidence of $\mathrm{AD} \cdot{ }^{[29-32]}$ Furthermore, there is evidence that indicates stroke and $\mathrm{AD}$ exacerbate the severity and prognosis of each other. ${ }^{[30,33,34]}$

Stroke, TBI, and other neurodegenerative diseases are characterized by the presence of delayed, progressive neuronal apoptosis involving caspase activation, suggesting a possible link between pathological molecular mechanisms and prospective targets for treatment. Early detection of specific apoptotic pathways using relevant biomarkers present in the cerebrospinal fluid (CSF) or peripheral blood would provide valuable information about progression of the neurodegenerative processes following brain injuries and suggest possible treatment interventions. The main focus of this review is to provide the current information on clinical studies of biomarkers involved in caspase-3-mediated apoptosis following TBI and stroke by focusing on the association of these biomarkers with clinical outcomes. The possible cellular and molecular mechanisms associated with these biomarkers and their clinical implications are also discussed.

\section{Pathways Involved in Cell Death Following Brain Injuries and Neurodegenerative Diseases: Role of Apoptosis}

Role of apoptosis in the central nervous system Neuronal cell death is involved in the etiopathology of many brain injuries, neurological disorders, and neurodegenerative disease including stroke, TBI, AD, and PD. ${ }^{[35]}$ Necrosis and apoptosis are two major mechanisms of cell death in the central nervous system (CNS) with distinct physiological and pathophysiological features, biochemical pathways, and histological descriptions. ${ }^{[36-38]}$ Necrosis generally occurs in direct response to a pathological stimulus, such as excitotoxicity generated during acute brain injuries or chronic neurological disorders and diseases by activation of a calpain-meditated cell death pathway. ${ }^{[37]}$ In contrast, apoptosis is involved in both physiological and pathophysiological processes and can result in selective cell death in response to a specific death stimulus. During apoptosis, cell death is caused by a tightly regulated biochemical cascade involving activation of caspases. ${ }^{[39,40]}$

Although both calpain- and caspase-mediated cell death mechanisms often coexist, in neurological disorders such as cerebral ischemia and brain trauma, necrosis and apoptosis are differentially involved in the etiopathology of these disorders and characterized by different spatiotemporal representations. ${ }^{[36]}$ Following acute brain injuries such as cerebral ischemia and brain trauma, necrosis plays a major role in the cell death within injured areas (e.g., infarct core and contusion zone, respectively), resulting in the formation of primarily irreversible brain lesions, in contrast to apoptosis which can extend delayed cell death into potentially treatable perilesional areas, often referred as penumbra. Thus, taking into account the brain's very limited capacity for neurogenesis and regeneration, ${ }^{[38,40-44]}$ apoptotic cell death pathways may represent potential targets for therapeutic treatment of brain injuries and stroke. ${ }^{[45]}$ In the CNS, necrosis primarily occurs in neurons whereas apoptosis is present in both in neuronal and nonneuronal cells. Understanding of the detailed molecular mechanisms and recognition of spatiotemporal profiles of apoptotic pathways in different acute brain injuries and neurodegenerative diseases are an important step for target-based development of novel therapeutic strategies for acute injury as well as neurological disorders.

Under physiological conditions, apoptosis plays an important role in maintaining the integrity and functionality of the CNS and peripheral nervous system during development, as well as neuro- and synapto-genesis and synaptic function and plasticity, by inducing a cell death sequence, or apoptotic cascade, in selected old or damaged cells while leaving surrounding cells intact. ${ }^{[46-50]}$ Neuronal apoptosis in the embryonic brain is a highly, genetically regulated process which plays a significant role for normal CNS development and function. ${ }^{[50-53]}$ However, abnormal apoptosis resulting in excessive neuronal and glial cell death and disrupted synaptic function plays an important role in the progression of brain injury and neurodegenerative diseases. ${ }^{[39]}$ 


\section{Apoptotic pathways and caspase activation}

Genetic and molecular determinants of apoptotic cell death pathways are well understood. Seminal studies performed in the nematode Caenorhabditis elegans identified four major genes controlling programmed cell death (ced-3, ced-4, egl-1, and ced-9). The orchestrated expression of these genes and their involvement in the cell death process laid a foundation for our current understanding of apoptosis in more complex organisms. ${ }^{[39,40,54-58]}$ In mammalians and other vertebrates, cellular apoptosis is regulated by expression of caspase proteases which are related to the ced-3 gene of C. elegans. Fourteen vertebrate caspases have been described to date, eleven of which are expressed in humans. ${ }^{[59]}$ Activation of caspases plays a major role in apoptotic events in acute and chronic neurological disorders, such as stroke, TBI, and other neurodegenerative diseases. ${ }^{[39,60-62]}$

Apoptotic cell death consists of a stereotypic biochemical pathway involving activation of different signal molecules and caspase proteases. ${ }^{[39]}$ Caspase activation involves several cleavage steps and processing from procaspases or caspase precursors, comprising p10 and p20 subunits, to activate caspase heterotetramers consisting of two p 10 and two p20 subunits derived from these procaspases. Functionally and structurally, caspases are categorized into upstream initiator caspases and downstream effector caspases. All initiator caspases have long N-terminal activation prodomains, and all effector caspases have short N-terminal activation prodomains. Further, initiator caspases are structurally subcategorized into two groups based on the presence of specific a long N-terminal procaspase activation domain, which also determine the caspase's specificity for signal molecules required for its activation including caspase-recruiting domain (caspases 1, 2, 4, 5, 9, 11, 12, and 13) or death-effector domain (caspases 8 and 10). ${ }^{[63-65]}$ Activation of upstream initiator caspases precedes and is required for activation of downstream effector caspases. ${ }^{[63,64]}$ Although many of these caspases are implicated in neurological disorders, they are differentially involved in cellular responses to the CNS injury and the etiopathology of neurodegenerative diseases, including both apoptotic and apoptosis-independent inflammatory pathways. The initiator caspases 2, 8, 9, and 10 and effector caspases 3, 6, and 7 are involved in apoptosis, whereas caspases 1, 4, 5, 11, 12, and 13 and caspase-14 are involved in cytokine activation and maturation, respectively. ${ }^{[64]}$

Apoptotic cell death includes three major stages: initiation, effector, and degradation phases. ${ }^{[39]}$ Apoptotic processes might be initiated involving both caspase-dependent and caspase-independent pathways. The caspase-dependent pathways can be activated by specific independent or converging intrinsic and extrinsic cell signaling mechanisms and involve specific caspases. The terminal phase of apoptotic cell death is initiated by cleavage of specific enzyme proteins by activated effector caspases such as poly (ADP-ribose) polymerase (PARP) and DNA-dependent protein kinase catalytic subunit (DNA-PKCS) resulting in the DNA degradation and fragmentation of cell nuclei. ${ }^{[66-69]}$ In addition, effector caspase proteases, notably caspase- 3 , are involved in the cleavage of specific cytoskeletal proteins (discussed in detail later in this review) that also play critical roles in cell death in neurological and neurodegenerative disorders. On the other hand, caspase- 1 activation leads to induction of nonapoptotic pathways resulting in the induction of inflammation and programmed cell death known as pyroptosis associated with the release of inflammatory cytokines. Simplified pathways involved in aforementioned mechanisms of cell death are presented in Figure 1.

\section{Intrinsic mechanisms of classic apoptosis}

Apoptosis through intrinsic mechanisms is associated with the activation of highly regulated multi-step mitochondria-dependent pathways resulting in activation of executor caspases, leading to cleavage of several cellular proteins promoting cell death. The initiation phase of apoptosis is induced by several stressors such as oxidative stress, genetic mutations, deficits of growth factors, and excitotoxicity, which activate an intracellular biochemical cascade involving one or more different joints and/or mutually independent mechanisms including increases in the cytosolic levels of free calcium ions $\left(\mathrm{Ca}^{2+}\right)$ and reactive oxygen species, upregulation of prostate apoptosis response- 4 protein (Par-4), and translocation of proapoptotic proteins from B-cell lymphoma-2 (Bcl-2) family, such as Bcl-2-associated X-protein (Bax) and $\mathrm{Bcl}-2$-associated death promoter (Bad) from the cytoplasm to the mitochondrial membrane, leading to initiation of the apoptotic cascade in mitochondria. ${ }^{[70,71]}$ The effector phase of apoptosis involves increases in the mitochondrial levels of $\mathrm{Ca}^{2+}$ and reactive oxygen radicals, the formation of permeability transition pores in the mitochondrial membrane, which allows transportation of cytochrome c from the mitochondria into the cytosol where it forms a complex with apoptotic protease-activating factor 1 (Apaf-1) involving in the activation of an initiator caspase (i.e., caspase-9) leading to processing and activation of executor caspases (e.g., caspases 3 and 7 ) that initiate the degradation phase of apoptosis. The current published data indicate that apoptotic cell death following brain injuries and neurodegeneration is primarily associated with activation of caspase- 3 although there are limited data for the involvement of caspase-7. Activation of the executor caspases involves multiple steps including cytochrome C-induced formation of an Apaf-1-caspase-9 apoptosome complex, ${ }^{[72]}$ subsequent cleavage, and 


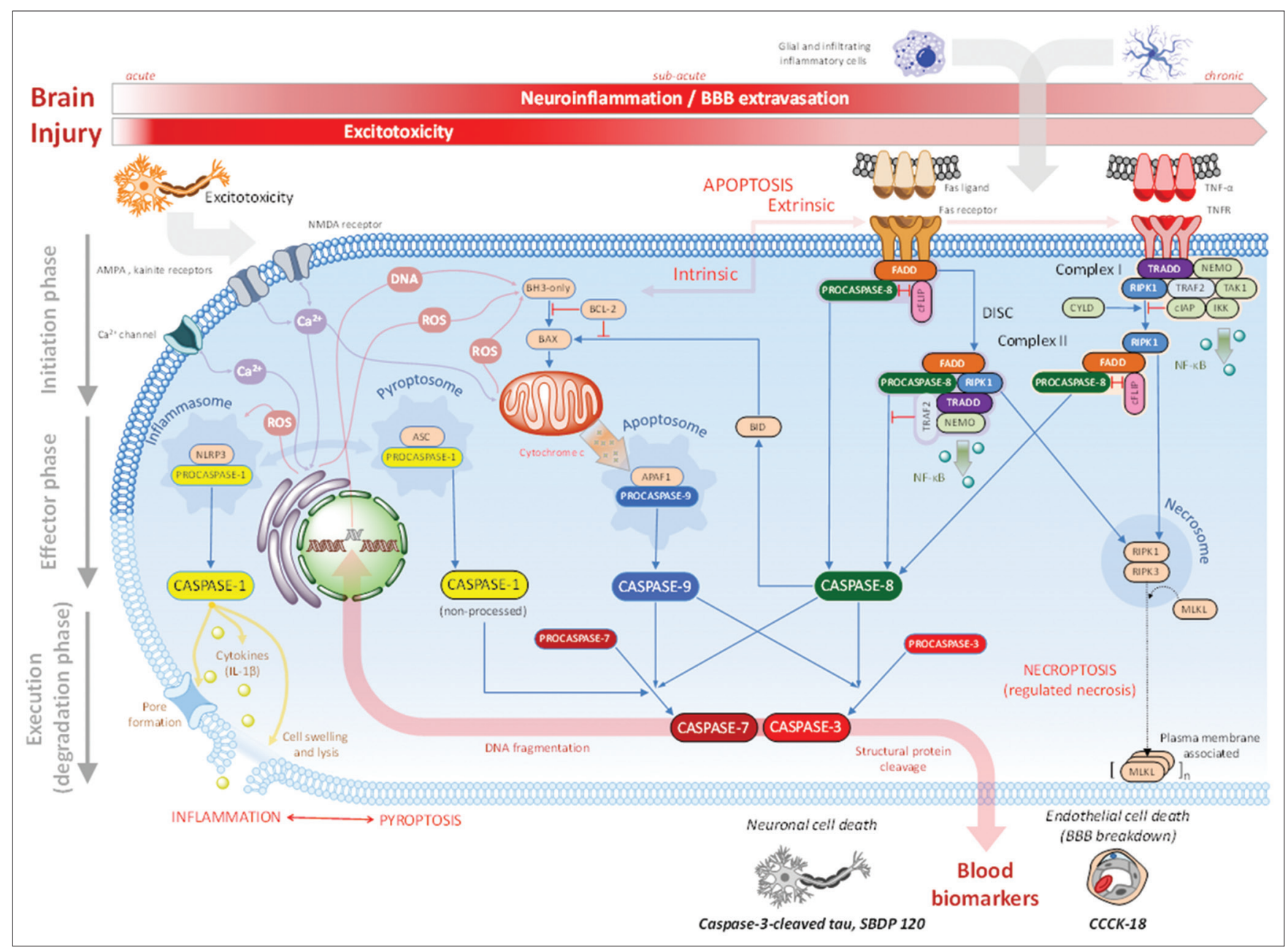

Figure 1: Cell death pathways following brain injury

processing of procaspase-3 and/or procaspase-7 resulting in activation of caspase-3 and/or caspase-7, effector caspase family members [Figure 1]. The execution caspases are involved in the cleavage of certain cellular proteins that result in the characteristic alteration of the plasma membrane structure and increased membrane permeability, and fragmentation of nuclear chromatin, all characteristics of apoptotic cell death.

Extrinsic mechanisms of classic apoptosis and the convergence of extrinsic and intrinsic pathways Certain caspases (e.g. caspases 8 and 10) leading to activation of executor caspase- 3 or caspase- 7 might be involved in the apoptotic pathways induced by activation of surface death receptors, the processes primarily independent of mitochondrial signaling (i.e., cytochrome C-mediated Apaf- 1 activation). ${ }^{[73]}$ Currently known death receptor pathways that have been linked with subsequent cell death as a consequence of neurovascular disorders, including stroke, TBI, and neurodegenerative diseases, are largely a result of the family of cytokine receptors, known as tumor necrosis factor receptors (TNFRs) which associate with extracellular signaling ligands such as cytokine tumor necrosis factor- $\alpha$ (TNF- $\alpha)$ and Fas. Subsequently, specific adaptor proteins incuding tumor necrosis factor receptor type 1-associated death domain (TRADD) and Fas-sssociated protein with death domain (FADD) can form death-initiating signaling complexes (DISCs) inside the cytoplasm that can initiate a subsequent cascade of caspase activation [Figure 1].

Expression of Fas and/or Fas ligand has been reported in stroke ${ }^{[74,75]}$ and severe TBI patients ${ }^{[76-78]}$ and documented in preclinical models of brain ischemia ${ }^{[79-81]}$ and TBI. ${ }^{[82-85]}$ Upregulation of TNF- $\alpha$ has been reported in clinical stroke studies including ischemic ${ }^{[86-88]}$ and animal TBI models. ${ }^{[83-85,89,90]}$ TNF- $\alpha$ might contribute to neuronal injury as well as exert protective effects ${ }^{[91]}$ Clinical data also suggest that, following brain injuries, extrinsic pathways are more delayed as compared to intrinsic pathways. For example, a significant association between upregulation of caspase 3 and soluble Fas levels has been reported on day 5 after TBI. ${ }^{[77]}$

In addition, activation of TNFR1 and further processing of formation of receptor-interacting protein kinase 
1 (RIPK1) and the RIPK3 complex, along with the recruitment of mixed lineage kinase domain-like, lead to activation of another highly regulated and genetically controlled necrotic cell death mechanisms often referred to as necroptosis (to distinguish with nonregulated necrosis). ${ }^{[92]}$

Extrinsic apoptotic mechanisms are also associated with the release of nuclear factor $\kappa$-light-chain-enhancer of activated B-cells (NF- $\kappa \mathrm{B})$, a transcription factor that regulates the expression of a wide array of immune response genes which could trigger differential pathways including upregulation mitogen-activated protein kinases ${ }^{[93]}$ and subsequent activation of pro-inflammatory cytokines. ${ }^{[91,94]}$ Time-dependent NF- $\mathrm{\kappa B}$ upregulation has been reported in TBI patients ${ }^{[05,96]}$ and animal TBI models. ${ }^{[99,90,97-100]}$ In TBI, NF- $\mathrm{KB}$ plays a key role in astrocytic swelling and edema formation that might further worsen brain injury. ${ }^{[99,100]}$

However, there are differences between the levels of caspase-8 produced following activation of death receptor and DISC formation between cell types, so-called cell Type I and cell Type II, involving different apoptotic mechanisms. ${ }^{[101,102]}$ The major pathway of death receptor activation in the cell Type I amount involves caspase- 8 production sufficient for direct cleavage of procaspase and activation of executor caspases 3 and 7, whereas in the cell Type II, the smaller amount of DISCs and active caspase- 8 production triggers activation of intrinsic mitochondria-dependent pathway of executor caspase activation $^{[101,102]}$ through cleavage of Bid, a Bcl-2-intracting protein involved in activation of apoptotic signaling in mitochondria and cytochrome c release.$^{[103,104]} \mathrm{Bid}$ cleavage associated with activation of both caspases 8 and 9 has been reported in preclinical TBI model, suggesting the involvement of convergent intrinsic and extrinsic mechanisms in brain injury progression. ${ }^{[105]}$

\section{Role of Caspase-mediated Apoptosis in Neurodegenerative Disorders: Possible Link between Acute Brain Injury and Chronic Neurodegeneration}

Recent clinical and experimental data indicate that TBI and other acute brain injuries share many common features with neurodegenerative disorders, including chronic inflammatory and neurovascular pathologies and apoptosis. ${ }^{[39,106-108]}$ The molecular and cellular mechanisms triggering the development of these pathologies and their progression following brain injuries are poorly understood; caspase-mediated apoptotic pathways associated with irregular accumulation of different tau are considered one possible factor linking development of neurodegenerative disease following acute brain injury.
Upregulation of several caspases has been demonstrated in human $\mathrm{AD}$ brain and genetic animal $\mathrm{AD}$ models including caspases 1, 3, 6, 7, 8 and 9. ${ }^{[109-113]}$ Activation of several caspases has been reported in transgenic animal AD models. ${ }^{[114,115]}$ Activated caspase-3 has long been implicated in AD pathophysiology, and its expression in different cell types including neurons, astrocytes, and blood vessels exhibited a high degree of colocalization with neurofibrillary tangles and senile plaques. ${ }^{[116]}$ Human studies have reported increased caspases 3 and 9 immunoreactivity in AD brain tissue as compared to controls ${ }^{[12,116]}$ though another study failed to find statistically significant differences in caspases 3 and 9 levels between AD and controls. ${ }^{[111]}$ Postmortem studies suggest that, in AD, a principle caspase pathway contributing to neuronal loss resulting from caspase-8-mediated induction of caspase-3 and/ or caspase-7.[111,117] Further, data indicate that increased caspase-3 activity and neuronal apoptosis appear in perivascular regions, an observation suggestive of involvement of caspase-3 in cerebrovascular injury. ${ }^{[118]}$

Clinical and experimental data indicate that caspase-3-mediated apoptosis plays a key role in cleavage of tau, an initial process underlying formation of fibrillary tangles and amyloid plaques that are commonly observed in $\mathrm{AD}$ and other neurodegenerative disorders ${ }^{[106,112,119-122]}$ and two the most recognized hallmarks of neurodegeneration. ${ }^{[123,124]}$ Numerous publications have suggested that caspase-3-cleaved tau found in neurofibrillary tangles might be one of the earliest biomarkers of AD. ${ }^{[106,120,121,125]}$ Recent studies have also demonstrated increased levels of caspse-3 cleaved tau in brain extracts of patients with $\mathrm{CTE}^{[126]}$ and in serum of both AD and TBI patients. ${ }^{[127,128]}$ In addition, caspase-3 activity is associated with proteolytic degradation of cytoskeletal proteins, such as $\alpha$ II-spectrin, further contributing to neuronal pathology in human TBI and animals models, ${ }^{[129,130]}$ and preclinical evidence suggests that this pathology might be exacerbated by the presence of existing neurodegenerative disease. ${ }^{[131]}$

\section{Caspase Activation and Apoptosis in Traumatic Brain Injury and Stroke}

Caspase-mediated apoptotic cell death has long been demonstrated in animal models of brain injuries including stroke and TBI. ${ }^{[132,133]}$ Experimental and clinical studies have also indicated that following cerebral ischemia and TBI, neural cellular death involves both caspase-mediated apoptotic and calpain-mediated necrotic cell death mechanisms. ${ }^{[132,134-138]}$ Further, numerous clinical and preclinical studies have shown that caspases are involved in the pathophysiology of many neurological disorders through complex apoptotic and inflammatory pathways. 
The seminal study performed by Friedlander et al. first demonstrated involvement of caspase- 1 in an animal model of ischemic stroke. ${ }^{[139]}$ Caspase- 1 is an upstream initiator caspase and plays an important role in inflammatory responses, neuronal apoptosis, and neurodegeneration following brain injuries. ${ }^{[137,139-142]}$ Further preclinical and clinical studies have shown activation of different caspases following cerebral ischemia (caspases 1, 3, 8, 9, and 11) $)^{[143-145]}$ and TBI (caspases 1, 3, 6, 7, 8, 9 and 12). ${ }^{[146-153]}$ Caspase-dependent pathways have also been revealed in acute subdural hematoma. ${ }^{[154]}$

Although there are similarities in caspase involvement in acute brain injuries and neurodegenerative diseases, mechanisms activation of certain caspases might differ and represent specific pathways characteristic of these conditions. For example, a preclinical rodent study suggests that caspase-2 is involved neuronal degeneration in a mouse AD mode ${ }^{[115]}$ but not involved in ischemic brain damage following experimental stroke. ${ }^{[145]}$

The activation of different caspases in these studies suggests involvement of both intrinsic and extrinsic apoptotic mechanisms as well as caspase-1-mediated inflammation and pyroptotic cell death in both TBI and stroke although these mechanisms might be involved differently depending on postinjury time point and injury phenotype.

The pathways involved in caspase activation following cerebral ischemia include translocation of Bcl-2 family proteins ${ }^{[155-157]}$ and cytochrome $\mathrm{c}$ release ${ }^{[143-145]}$ suggesting involvement of intrinsic apoptotic mechanisms. Intrinsic cytochrome c and Bcl-2 mediated apoptotic pathways involving activation of caspases 9 and 3 have been also reported in adult ${ }^{[152,158,159]}$ and pediatric ${ }^{[159-161]}$ clinical TBI studies.

Activation of caspase-3 through caspase-8-mediated pathways in $\mathrm{TBI}^{[78,151]}$ and stroke ${ }^{[86,88,162]}$ pathology suggests involvement of extrinsic apoptotic mechanisms in these disorders. Notably, similar pathways are involved in neurodegenerative disease. ${ }^{[111,117]}$ Involvement of extrinsic apoptotic mechanisms is also suggested from clinical studies showing correlations of caspase-3 and/or caspase-8 activation with upregulation of death receptors (e.g., Fas) and death receptors ligands (e.g., TNF- $\alpha$ ) in stroke ${ }^{[74,86-88]}$ and TBI ${ }^{[77,151]}$ patients. Similar findings were reported in preclinical models of stroke $\mathrm{e}^{[143,163-165]}$ and TBI. . $^{[82,147,151,166]}$

Acute neuronal apoptosis after TBI was observed primarily within the injury site, whereas delayed neuronal apoptosis lasting days and weeks after TBI occurred mainly in remote, indirectly impacted regions. ${ }^{[167-169]}$

\section{Involvement of Different Cellular Types and Mechanisms in Caspase-mediated Apoptosis in Stroke and Traumatic Brain Injury}

Although neuronal cell death plays a major role in brain dysfunction following brain injuries and neurodegenerative diseases, the current data indicate that apoptosis in nonneuronal cell types plays an important role in the progression of these disorders. In addition, activation of caspases following brain injuries can exacerbate inflammation and affect glial function by induction of apoptosis and activation of microglia. Both neuronal and glial apoptosis have been reported in several experimental and clinical studies including acute CNS injuries such as stroke, ${ }^{[170]} \mathrm{TBI}$, and spinal cord injuries, ${ }^{[136]}$ as well as chronic neurodegenerative diseases. Activated caspase- 3 upregulation at acute time points after experimental TBI was observed primarily in neurons and to a lesser extent, in astrocytes and oligodendrocytes. ${ }^{[146,147]}$

Expression of cleaved caspases 8 and 3 have been reported in Iba1-positive microglia in animal models of cerebral ischemia and in CD68-positive microglia/macrophages in ischemic human stroke. ${ }^{[162,171,172]}$ Other published data suggest that TBI-induced white matter degeneration and myelin loss in corpus callosum may result from oligodendrocyte apoptosis..$^{[173-175]}$ An increased number of activated caspase-3-immunopositive oligodendrocytes in the corpus callosum was observed starting at $48 \mathrm{~h}$ after injury and remained elevated for up to 3 weeks following fluid percussion injury in rats. This activated caspase- 3 upregulation was associated with decreased numbers of healthy oligodendrocytes, suggesting that apoptosis had occurred. ${ }^{[173-175]}$

\section{Caspase Inhibition as a Novel Neuroprotective Strategy for Stroke and Traumatic Brain Injury}

Preclinical evidence indicates that delayed activation of caspase-mediated apoptosis following stroke, TBI, intracerebral hemorrhage, and SAH primarily occurs in potentially treatable penumbral and perilesional areas providing potential therapeutic opportunities for targeting apoptotic pathways to limit the expansion of brain lesions. ${ }^{[45,176]}$

Preclinical studies using pharmacological inhibition with pan- and selective caspase inhibitors, and using genetically modified caspase-deficient (e.g., caspases 1 and 11) animals, have reported that decreasing activity of selected caspases improves neurological deficits and provides neuroprotection from cerebral ischemia primarily in penumbral regions, ${ }^{[139,143,145,155,177-180]}$ following acute subdural hematomas. ${ }^{[154]}$ 


\section{Apoptotic Biomarkers and Their Association with Brain Injury Outcomes}

Over the past two decades, several clinical studies have examined biomarkers of apoptosis following acute brain injuries. These biomarkers include the caspase proteases, notably caspase-3, and their specific cleavage products such as caspase-cleaved cytokeratin-18 (CCCK-18), caspase-cleaved tau, and caspase-specific $\alpha$ II-spectrin breakdown products (SBDPs). Clinical studies focusing on the detection of apoptotic biomarkers in brain tissue and biofluids are summarized in Table 1.

Increases in the levels of certain caspases following brain injuries are suggestive of involvement of pathological pathways such as apoptosis and inflammation, as well as injury severity. Similarly, levels of caspase-specific cleavage products such as CCCK-18, caspase-cleaved tau, and caspase-specific SBDP120 are both indicative of cellular involvement of specific cell types and also provide information on injury mechanisms. In addition, use of a panel comprising cells-specific glial and neuronal biomarkers of brain injuries would provide additional valuable information on the injury mechanisms in the involvement of different cell populations making it possible for evidence-based diagnostics and personalized treatment of stroke and TBI patients. ${ }^{[203,204]}$

\section{Caspase-3 as a Major Biomarker of Brain Apoptosis following Stroke and Traumatic Brain Injury}

Experimental and clinical studies have provided evidence that activated caspase- 3 is a key player in cellular death following acute brain injuries and might be involved in the progression of chronic neurodegenerative processes. In preclinical TBI models, the upregulation of activated caspase- 3 in the ipsilateral cortex was observed from 6 to $72 \mathrm{~h}$ with maximal increase at $48 \mathrm{~h}$ after controlled cortical impact, whereas no evidence of caspase- 3 activation was observed in the ipsilateral hippocampus and contralateral cortex and hippocampus up to 14 days after injury. ${ }^{[146,147]}$ Similarly, acute increase of cleaved-caspase- 3 in neurons has been observed in the injured cortex after fluid-percussion injury. ${ }^{[205]}$ In a model of surgical brain injury, the upregulation of caspase- 3 was observed mainly in neurons within the injured cortex, and this upregulation was transient, peaking at 5 days and then gradually decreased within the next 3 weeks. ${ }^{[206]}$

Numerous clinical studies have demonstrated upregulation of caspase- 3 following ischemic and hemorrhagic strokes and TBI in postmortem and surgically removed brain tissues, ${ }^{[74,77,95,157-159,162,171,172,180,195]}$ CSF, ${ }^{[77,197]}$ and blood plasma. ${ }^{[86-88,181-183]}$ Other major caspases that are upregulated following activation after injuries include caspase- $1,{ }^{[158,191]}$ caspase- $7,{ }^{[86,148]}$ and caspase-8. ${ }^{[7,78,88]}$ Immunohistochemical studies revealed that caspase- 1 upregulation was observed in the brain tissue, blood vessels, T-lymphocytes, and CD68positive macrophages; these caspase- 1 increases were associated with Bcl-2, interleukin $1 \beta$, and NLRP3 levels. ${ }^{[158,191]}$ Caspase-3 upregulation was observed in neurons ${ }^{[157,180]}$ and in CD68-positive cells, including infiltrating macrophages and microglia. ${ }^{[162,171,172]}$ Caspase 8 was primarily expressed in neurons ${ }^{[78]}$ and caspase-7 was expressed in astrocytes, neurons, and other glial and infiltrated inflammatory cells..$^{[148]}$

Caspase3 upregulation was associated with other apoptotic and cellular injury markers including caspase-3 substrates DNA-PKCS and PARP, end-product of PARP activity poly (ADP-ribose), phosphorylated c-Jun N-terminal kinases 1 and 2, and terminal transferase-mediated dUTP-digoxigenin nick end-labelling (TUNEL), an indicator of DNA fragmentation. ${ }^{[7,157,172]}$

Increases in caspases 3 and 8 expression and activity in both TBI and stroke samples have been reported in association with changes in TNF- $\alpha, \mathrm{NF}-\kappa \mathrm{B}$, and Fas levels, ${ }^{[74,75,77,78,95]}$ suggesting the involvement of caspase- 8 and death receptors in activation of caspase- 3 following injury. ${ }^{[73]}$

Elevated plasma caspase-3 levels and caspase-3/7 activity in stroke patients have been reported in both acute $^{[86,181]}$ and late phases of stroke for up to 6 months after cerebral injury. ${ }^{[88]}$ A study by Montaner et al. has shown that a combination of caspase- 3 and d-dimer might be a promising biochemical strategy for rapid diagnosis of stroke. ${ }^{[183]}$ Acute increases in caspase-3 levels were associated with infarct growth and short- and long-term neurological outcomes. ${ }^{[181]}$ Significant increases in acute caspase-3/7 activity in blood were observed only in patients with gray matter lesions, suggesting that apoptosis occurs primarily in neurons. ${ }^{[86]}$ However, spatiotemporal analysis of cleaved caspase- 8 and- 3 expression in postmortem brain tissue of stroke patients suggests that changes in their activities following cerebral ischemia can also occur in microglia / macrophages. ${ }^{[162]}$ In addition, acute caspase- $3 / 7$ activation in blood plasma and blood levels of caspase- 3 and 8 in late phase of stroke were significantly correlated with TNF- $\alpha$ levels in blood plasma $^{[86,88]}$ and platelets. ${ }^{[87]}$

A recent study by Wang et al. revealed that caspase-3 activation at admission and at day 3 in aneurysmal SAH patients was increased in those patients who had an unfavorable outcome or died. These levels were highly associated with the severity of injury and prognosis 
Table 1: Expression of apoptotic biomarkers following acute brain injuries

\begin{tabular}{|c|c|c|c|c|c|}
\hline Clinical study & Biomarker & Time points & $\begin{array}{l}\text { Subjects, group } \\
\text { size, and age }\end{array}$ & Matrix/levels & Results \\
\hline $\begin{array}{l}\text { Ischemic stroke and } \\
\text { ischemia-reperfusion } \\
\text { injury }{ }^{[172]}\end{array}$ & $\begin{array}{l}\text { Caspase-3 } \\
\text { (activated) }\end{array}$ & $12 \mathrm{~h}$ to 9 days & $\begin{array}{l}11 \text { patients with } \\
\text { atherothrombotic } \\
\text { brain infarct } \\
11 \text { patients with } \\
\text { cardiac arrest } \\
\text { resuscitation } \\
\text { (ischemia-reperfusion } \\
\text { injury) (46-95 years) }\end{array}$ & $\begin{array}{l}\text { Brain tissue } \\
\text { (postmortem) }(\mathrm{IHC})\end{array}$ & $\begin{array}{l}\text { Caspase-3 upregulation in } \\
\text { macrophages/microglia and limited } \\
\text { upregulation in neurons } \\
\text { Differential caspase-3 upregulation } \\
\text { in transient ischemia-reperfusion } \\
\text { injury and permanent cerebral } \\
\text { ischemia (atherothrombotic brain } \\
\text { infarcts) } \\
\text { Association of caspase-3 } \\
\text { upregulation with } \\
\text { caspase-3-cleaved PARP ( } 89 \mathrm{kDa})\end{array}$ \\
\hline Ischemic stroke ${ }^{[180]}$ & Caspase-3 & $\begin{array}{l}4,8,16,24,48 \\
72,130,192 \mathrm{~h}\end{array}$ & $\begin{array}{l}48 \text { patients } \\
\text { (40-70 years, average } \\
\text { age } 60.8 \text { years) }\end{array}$ & $\begin{array}{l}\text { Brain tissue } \\
\text { (postmortem) (in situ } \\
\text { hybridization and } \\
\text { IHC) }\end{array}$ & $\begin{array}{l}\text { Time-dependent caspase } 3 \\
\text { upregulation in hippocampus (CA1) } \\
\text { Association of caspase-3 } \\
\text { upregulation with TUNEL and loss } \\
\text { of MAP-2 }\end{array}$ \\
\hline Ischemic stroke ${ }^{[157]}$ & $\begin{array}{l}\text { Caspase-3 } \\
\text { (activated) }\end{array}$ & 2-37 days & $\begin{array}{l}18 \text { patients } \\
\text { (51-86 years) }\end{array}$ & $\begin{array}{l}\text { Brain tissue } \\
\text { (postmortem and ipsi- } \\
\text { and contra-lateral) } \\
\text { (Western blot and } \\
\text { IHC) }\end{array}$ & $\begin{array}{l}\text { Activated caspase- } 3 \text { upregulation in } \\
\text { neurons in the infarct area } \\
\text { Association of activated caspase- } 3 \\
\text { upregulation with TUNEL and } \\
\text { p-JNK } \\
\text { The presence of Bcl- } 2 \text { in penumbra } \\
\text { of gray matter significantly } \\
\text { correlated with shorter survival time }\end{array}$ \\
\hline Ischemic stroke $e^{[74]}$ & $\begin{array}{l}\text { Caspase-3 } \\
\text { (activated) }\end{array}$ & $15 \mathrm{~h}$ to 18 days & $\begin{array}{l}13 \text { patients } \\
2 \text { controls } \\
\text { (41-89 years) }\end{array}$ & $\begin{array}{l}\text { Brain tissue } \\
\text { (postmortem, } \\
\text { peri-infarct area) } \\
\text { (IHC) }\end{array}$ & $\begin{array}{l}\text { Cytoplasmic activated caspase-3 } \\
\text { immunopositivity correlated with } \\
\text { death receptor Fas } \\
\text { Nuclear and cytoplasmic PARP-1 } \\
\text { differentially correlated with } \\
\text { increasing neuronal necrosis in the } \\
\text { peri-infarct area }\end{array}$ \\
\hline Ischemic stroke ${ }^{[181]}$ & Caspase-3 & $\begin{array}{l}12 \text { and } 24 \mathrm{~h} \\
\text { from stroke } \\
\text { onset and } 2 \mathrm{~h} \\
\text { after tPA }\end{array}$ & $\begin{array}{l}116 \text { tPA-treated } \\
\text { stroke patients (mean } \\
\text { age } 71.8 \pm 11.3 \text { years) } \\
40 \text { healthy control } \\
\text { subjects (mean age } \\
60.5 \pm 9.4 \text { years) }\end{array}$ & Blood plasma & $\begin{array}{l}\text { Plasma caspase- } 3 \text { levels were } \\
\text { higher in stroke patients versus the } \\
\text { control group throughout the acute } \\
\text { phase of stroke } \\
\text { Plasma caspase- } 3 \text { level at } 24 \mathrm{~h} \text { was } \\
\text { associated with poorer short- and } \\
\text { long-term neurological outcomes } \\
\text { and positively correlated with infarct } \\
\text { volume }\end{array}$ \\
\hline Ischemic stroke ${ }^{[86]}$ & $\begin{array}{l}\text { Caspase- } 3 / 7 \\
\text { activity }\end{array}$ & Acute & $\begin{array}{l}7 \text { patients } \\
4 \text { controls } \\
\text { (39-82 years) }\end{array}$ & Blood plasma & $\begin{array}{l}\text { Relative caspase- } 3 / 7 \text { activity in } \\
\text { plasma was significantly correlated } \\
\text { with the soluble TNF- } \alpha \text { levels but not } \\
\text { with the membrane-associated TNF- } \square \\
\text { levels or density of plasma DNA }\end{array}$ \\
\hline Ischemic Stroke ${ }^{[87]}$ & $\begin{array}{l}\text { Caspase-3 } \\
\text { expression }\end{array}$ & Acute & $\begin{array}{l}60 \text { patients } \\
\text { (55-70 years, mean } \\
\text { age } 57.9 \pm 10.2 \text { years) } \\
45 \text { controls } \\
\text { (mean age } \\
51.05 \pm 9.07 \text { years) }\end{array}$ & $\begin{array}{l}\text { Blood plasma } \\
\text { Platelets (Western } \\
\text { blot and qRT-PCR) }\end{array}$ & $\begin{array}{l}\text { Stroke patients had significantly } \\
\text { increased in plasma TNF- } \alpha \text { and } \\
\text { platelet levels of annexin-V, CD62p, } \\
\text { cytochrome-c, and caspase3 gene } \\
\text { expression as compared to the } \\
\text { controls }\end{array}$ \\
\hline Stroke ${ }^{[171]}$ & Caspase-3 & $\begin{array}{l}18 \mathrm{~h} \text {-several } \\
\text { month }\end{array}$ & $\begin{array}{l}35 \text { patients } \\
\text { (46-95 years) }\end{array}$ & $\begin{array}{l}\text { Brain tissue } \\
\text { (postmortem) }(\mathrm{IHC})\end{array}$ & $\begin{array}{l}\text { Caspase- } 3 \text { upregulation in neurons } \\
\text { during the first } 2 \text { days after stroke } \\
\text { Caspase- } 3 \text { upregulation in } \\
\text { infiltrating macrophages during } \\
\text { between } 3 \text { days and } 3 \text { weeks after } \\
\text { stroke. } \\
\text { Association of caspase-3 } \\
\text { upregulation with other apoptotic } \\
\text { markers, PAR, PARP, DNA-PKCS, } \\
\text { and TUNEL }\end{array}$ \\
\hline
\end{tabular}


Table 1: Contd...

\begin{tabular}{|c|c|c|c|c|c|}
\hline Clinical study & Biomarker & Time points & $\begin{array}{l}\text { Subjects, group } \\
\text { size, and age }\end{array}$ & Matrix/levels & Results \\
\hline $\begin{array}{l}\text { Stroke and stroke } \\
\text { mimics }^{[182,183]}\end{array}$ & Caspase-3 & $\begin{array}{l}24 \mathrm{~h} \text { from } \\
\text { symptom onset }\end{array}$ & $\begin{array}{l}915 \text { stroke (mean age } \\
72.63 \pm 12.46 \text { years) } \\
90 \text { stroke mimics } \\
\text { patients (mean age } \\
69.57 \pm 17.13 \text { years) }\end{array}$ & $\begin{array}{l}\text { Blood plasma } \\
>1.96 \mathrm{ng} / \mathrm{mL}\end{array}$ & $\begin{array}{l}\text { The best combination of biomarkers } \\
\text { in the model predictive probability of } \\
\text { stroke was caspase- } 3 \text { and d-dimer } \\
\text { as compared to combinations } \\
\text { of RAGE, MMP-9, S100B, brain } \\
\text { natriuretic peptide, neurotrophin-3, } \\
\text { and chimeric secretagogin }\end{array}$ \\
\hline Stroke ${ }^{[88]}$ & $\begin{array}{l}\text { Caspase-3 } \\
\text { Caspase-8 }\end{array}$ & $>6$ months & $\begin{array}{l}40 \text { patients (average } \\
\text { age } 63 \pm 2.1 \text { years) } \\
40 \text { controls (average } \\
\text { age } 56 \pm 1.6 \text { years) }\end{array}$ & $\begin{array}{l}\text { Blood plasma } \\
\text { Caspase-3 } \\
\text { Patients: } \\
\text { 142.9 } 16.6 \mathrm{pg} / \mathrm{mL} \\
\text { Controls: } \\
28.9 \pm 0.87 \mathrm{pg} / \mathrm{mL} \\
\text { Caspase-8 } \\
\text { Patients: } \\
64.6 \pm 16.9 \mathrm{pg} / \mathrm{mL} \\
\text { Controls: } \\
50.1 \pm 1.3 \mathrm{pg} / \mathrm{mL}\end{array}$ & $\begin{array}{l}\text { Caspase- } 3 \text { and caspase- } 8 \text { levels } \\
\text { were significantly higher in stroke } \\
\text { patients as compared to controls } \\
\text { Stroke patients with dyslipidemia } \\
\text { had significantly higher caspase- } 3 \\
\text { and caspase- } 8 \text { levels than stroke } \\
\text { patients without dyslipidemia } \\
\text { and control groups. Caspase- } 3 \\
\text { and caspase-8 were significantly } \\
\text { correlated with TNF- } \alpha\end{array}$ \\
\hline Stroke ${ }^{[162]}$ & $\begin{array}{l}\text { Caspase-3 } \\
\text { Caspase-8 }\end{array}$ & $\begin{array}{l}\text { Days after } \\
\text { stroke }\end{array}$ & $\begin{array}{l}9 \text { subjects with } \\
\text { two stroke events } \\
\text { (average age } \\
75 \pm 9 \text { years) } \\
5 \text { controls (average } \\
\text { age } 75 \pm 11 \text { years) }\end{array}$ & $\begin{array}{l}\text { Brain tissue } \\
\text { (postmortem) }\end{array}$ & $\begin{array}{l}\text { Expression of cleaved caspase- } 8 \\
\text { and caspase- } 3 \text { in CD } 68 \text {-positive } \\
\text { cells could only be found in the area } \\
\text { of second stroke } \\
\text { Cleaved caspase- } 8 \text { and caspase- } 3 \\
\text { expressions correlated with the time } \\
\text { of stroke onset }\end{array}$ \\
\hline Stroke ${ }^{[184]}$ & $\begin{array}{l}\text { Caspase - } \\
\text { cleaved tau }\end{array}$ & $\begin{array}{l}\text { Admission, } 1 \\
\text { and } 7 \text { days }\end{array}$ & $\begin{array}{l}19 \text { patients (average } \\
\text { age } 61 \pm 13 \text { years) }\end{array}$ & $\begin{array}{l}\text { Serum } \\
\qquad \begin{array}{l}104.39 \pm 24.95 \\
\text { ng/mL }(7 \text { days, } \\
\text { NIHSS } \geq 6) \\
42.86 \pm 6.53 \mathrm{ng} / \mathrm{mL} \\
\text { (7 days, NIHSS } \leq 5)\end{array}\end{array}$ & $\begin{array}{l}\text { Significant difference in } \\
\text { caspase-cleaved tau levels } \\
\text { between patients with a good } \\
\text { outcome (NIHSS } \leq 5 \text { ) and patients } \\
\text { with a poor outcome (NIHSS } \geq 6 \text { ) } \\
\text { Significant elevation } \\
\text { caspase-cleaved tau level at day } 7 \\
\text { for patients with a poor outcome as } \\
\text { compared to patients with a good } \\
\text { outcome } \\
\text { No significant difference in } \\
\text { caspase-cleaved tau levels at } \\
\text { admission between the patients } \\
\text { with good and poor outcomes }\end{array}$ \\
\hline $\begin{array}{l}\text { Multiple cerebral } \\
\text { infarcts and } A D^{[75]}\end{array}$ & Caspase-8 & Postmortem & $\begin{array}{l}3 \text { stroke patients } \\
6 \text { AD patients } \\
7 \text { age-matched } \\
\text { controls } \\
\text { (72-96 years) }\end{array}$ & $\begin{array}{l}\text { Brain tissue } \\
\text { (postmortem) } \\
(\mathrm{IHC})\end{array}$ & $\begin{array}{l}\text { Activated caspase- } 8 \text { protein and } \\
\text { Fas-positive neurons were found } \\
\text { only in the AD brains and not in the } \\
\text { other groups }\end{array}$ \\
\hline $\begin{array}{l}\text { Transient cerebral } \\
\text { ischemia }^{[185]}\end{array}$ & Caspase-3 & $\begin{array}{l}\text { Cardiac arrest } \\
\text { or severe } \\
\text { hypotension }\end{array}$ & $\begin{array}{l}23 \text { patients with a } \\
\text { history of transient } \\
\text { hypoxic attacks } \\
11 \text { control (cases } \\
\text { with similar } \\
\text { systemic diseases) } \\
\text { (38-91 years, mean } \\
\text { age } 70.6 \pm 12.7 \text { years) }\end{array}$ & $\begin{array}{l}\text { Brain tissue } \\
\text { (postmortem) }\end{array}$ & $\begin{array}{l}\text { Upregulation of caspase- } 3 \text { and } \\
\text { redistribution cytochrome c in } \\
\text { a region-specific manner with } \\
\text { marked activation in the selectively } \\
\text { vulnerable hippocampal areas } \\
\text { Increases in TUNEL-positive cells } \\
\text { predominantly during the first } 3 \\
\text { days after ischemia in the regions } \\
\text { of greatest susceptibility to hypoxic } \\
\text { injury }\end{array}$ \\
\hline $\begin{array}{l}\text { Perinatal } \\
\text { hypoxic-ischemic brain } \\
\text { injury[186] }\end{array}$ & Caspase-3 & Postmortem & 6 patients & $\begin{array}{l}\text { Brain tissue } \\
\text { (postmortem) (IHC) }\end{array}$ & $\begin{array}{l}\text { Ccaspase- } 3 \text { activation and } \\
\text { apoptosis in pontosubicular neuron } \\
\text { necrosis }\end{array}$ \\
\hline
\end{tabular}


Table 1: Contd...

\begin{tabular}{|c|c|c|c|c|c|}
\hline Clinical study & Biomarker & Time points & $\begin{array}{l}\text { Subjects, group } \\
\text { size, and age }\end{array}$ & Matrix/levels & Results \\
\hline \multirow[t]{2}{*}{$\overline{\mathrm{SAH}}$ (aneurysmal) ${ }^{[194]}$} & \multirow[t]{2}{*}{ SBDP120 } & \multirow[t]{2}{*}{$\begin{array}{l}\text { Every } 6 \mathrm{~h} \\
\text { (up to } 72 \mathrm{~h} \text { ) }\end{array}$} & \multirow[t]{2}{*}{$\begin{array}{l}20 \text { patients } \\
1 \text { control } \\
\text { (34-77 years) }\end{array}$} & \multirow[t]{2}{*}{ CSF } & $\begin{array}{l}\text { SBDP120 and calpain-mediated } \\
\text { SBDPs were significantly increased } \\
\text { in patients suffering aneurysmal } \\
\text { SAH }\end{array}$ \\
\hline & & & & & $\begin{array}{l}\text { The concentration of SBDPs was } \\
\text { found to increase significantly } \\
\text { over baseline level up to } 12 \mathrm{~h} \\
\text { before the onset of cerebral arterial } \\
\text { vasospasm }\end{array}$ \\
\hline \multirow[t]{2}{*}{ TBI (severe) ${ }^{[76]}$} & \multirow[t]{2}{*}{ Caspase-1 } & \multirow[t]{2}{*}{$0-10$ days } & $\begin{array}{l}67 \text { patients }(0.1-16 \\
\text { median age } 6 \text { years })\end{array}$ & \multirow[t]{2}{*}{ CSF } & $\begin{array}{l}\text { Caspase-1 and Fas were increased } \\
\text { in CSF after TBI }\end{array}$ \\
\hline & & & $\begin{array}{l}19 \text { controls (without } \\
\text { trauma or meningitis) } \\
\text { (0.1-12 years, median } \\
\text { age } 1.7 \text { years) }\end{array}$ & & $\begin{array}{l}\text { Increased CSF cytochrome c was } \\
\text { independently associated with } \\
\text { inflicted TBI }(P=0.0001) \text { and female } \\
\text { gender ( } P=0.04) \text {, but not age, GCS } \\
\text { score, or survival }\end{array}$ \\
\hline \multirow[t]{2}{*}{$\mathrm{TB}^{[158]}$} & $\begin{array}{l}\text { Caspase-1 } \\
\text { (cleaved) }\end{array}$ & \multirow[t]{2}{*}{$\begin{array}{l}\text { Acute phase of } \\
\text { TBI }\end{array}$} & \multirow{2}{*}{$\begin{array}{l}8 \text { patients } \\
\text { ( } 21-57 \text { years, average } \\
\text { age } 35.9 \pm 4.4 \text { years) } \\
6 \text { controls } \\
\text { (16-77 years, average } \\
\text { age } 52.2 \pm 9.0 \text { years) }\end{array}$} & \multirow{2}{*}{$\begin{array}{l}\text { Brain tissue (TBI, } \\
\text { e surgically removed) } \\
\text { Brain tissue (control, } \\
\text { postmortem) }\end{array}$} & \multirow{2}{*}{$\begin{array}{l}\text { Cleavage of caspase- } 1 \text {, } \\
\text { up-regulation and cleavage of } \\
\text { caspase- } 3 \text {, evidence for DNA } \\
\text { fragmentation with both apoptotic } \\
\text { and necrotic morphologies and an } \\
\text { increase in Bcl-2 but not Bcl-xL or } \\
\text { Bax were found in tissue from TBI } \\
\text { patients compared with controls }\end{array}$} \\
\hline & $\begin{array}{l}\text { Caspase-3 } \\
\text { (cleaved) }\end{array}$ & & & & \\
\hline \multirow[t]{3}{*}{$\mathrm{TB}^{[159]}$} & \multirow[t]{3}{*}{ Caspase-3 } & \multirow{3}{*}{$\begin{array}{l}54 \pm 49 \mathrm{~h} \\
82 \pm 56 \mathrm{~h} \\
109 \pm 95 \mathrm{~h}\end{array}$} & \multirow{3}{*}{$\begin{array}{l}29 \text { patients } \\
3 \text { controls (epilepsy) } \\
\text { (12-72 years, mean } \\
\text { age } 28.3 \pm 15.3 \text { years) }\end{array}$} & \multirow{3}{*}{$\begin{array}{l}\text { Brain tissue (TBI } \\
\text { peri-ischemic zone, } \\
\text { surgically removed) }\end{array}$} & \multirow{2}{*}{$\begin{array}{l}\text { Significant caspase- } 3 \text { upregulation } \\
\text { in patients who died (GOS score } 1 \text {, } \\
n=12 \text { ) as compared to patients } \\
\text { experienced a good outcome (GOS } \\
\text { score } 4 \text { or } 5, n=17 \text { patients) }\end{array}$} \\
\hline & & & & & \\
\hline & & & & & $\begin{array}{l}\text { Bcl-2 (negative) and caspase-3 } \\
\text { (positive) are independent } \\
\text { predictors of poor outcome }\end{array}$ \\
\hline \multirow[t]{3}{*}{$\mathrm{TB}^{[95]}$} & \multirow[t]{3}{*}{ Caspase-3 } & \multirow{3}{*}{$\begin{array}{l}0,12,24,48,72 \\
168,264, \text { and } \\
480 \mathrm{~h}\end{array}$} & $\begin{array}{l}39 \text { patients (dead } \\
\text { from TBI) }\end{array}$ & \multirow[t]{3}{*}{$\begin{array}{l}\text { Brain tissue } \\
\text { (postmortem) (IHC) }\end{array}$} & $\begin{array}{l}\text { Marked caspase- } 3 \text { upregulation in } \\
\text { every injured group compared to }\end{array}$ \\
\hline & & & 8 controls (dead from & & controls \\
\hline & & & $\begin{array}{l}\text { none TBI reasons) } \\
\text { (average age } \\
34.8 \text { years) }\end{array}$ & & $\begin{array}{l}\text { Time-depending upregulation of } \\
\text { NF- } \square B \text { in } 168-480 \mathrm{~h} \text { groups after TBI }\end{array}$ \\
\hline \multirow[t]{3}{*}{$\mathrm{TB}^{[195]}$} & \multirow[t]{3}{*}{ Caspase-3 } & \multirow[t]{3}{*}{$\begin{array}{l}\text { Few minutes to } \\
126 \text { days }\end{array}$} & \multirow[t]{3}{*}{$\begin{array}{l}56 \text { patients } \\
\text { (14-86 years, average } \\
\text { age } 47.3 \text { years) }\end{array}$} & \multirow[t]{3}{*}{$\begin{array}{l}\text { Brain tissue } \\
\text { (postmortem) (IHC } \\
\text { and in situ labeling) }\end{array}$} & $\begin{array}{l}\text { Caspase- } 3 \text { upregulation in cortical } \\
\text { neurons was detectable } 80 \mathrm{~min} \\
\text { after TBI }\end{array}$ \\
\hline & & & & & $\begin{array}{l}\text { Caspase- } 3 \text { upregulation in glial cells } \\
\text { was detectable } 80 \mathrm{~min} \text { after TBI }\end{array}$ \\
\hline & & & & & $\begin{array}{l}\text { Cerebral apoptosis was significantly } \\
\text { associated with TBI compared to } \\
\text { control }\end{array}$ \\
\hline \multirow[t]{3}{*}{ TB| $\left.\right|^{[196]}$} & \multirow[t]{3}{*}{ Caspase-3 } & \multirow[t]{3}{*}{$0-96 \mathrm{~h}$} & \multirow{3}{*}{$\begin{array}{l}12 \text { patients } \\
\text { (18-81 years, mean } \\
\text { age } 42 \text { years) } \\
2 \text { controls (sudden } \\
\text { death) (mean age } \\
52 \text { years) }\end{array}$} & $\begin{array}{l}\text { Brain tissue } \\
\text { (postmortem) }\end{array}$ & \multirow{3}{*}{$\begin{array}{l}\text { Significant increase in caspase- } 3 \\
\text { and TrkB in the cerebellum of } \\
\text { patients with short survival times as } \\
\text { compared to controls }\end{array}$} \\
\hline & & & & (RT-PCR) & \\
\hline & & & & & \\
\hline \multirow[t]{2}{*}{$\mathrm{TB}^{[197]}$} & \multirow[t]{2}{*}{$\begin{array}{l}\text { Caspase-3 } \\
\text { (activated) }\end{array}$} & $1-14$ days & $\begin{array}{l}27 \text { patients (average } \\
\text { age } 36.1 \pm 12.9 \text { years) }\end{array}$ & CSF & $\begin{array}{l}\text { Caspase-3 activity was detected } \\
\text { in } 31(27.4 \%) \text { CSF samples with }\end{array}$ \\
\hline & & & $\begin{array}{l}7 \text { controls (average } \\
\text { age } 41.6 \pm 9.8 \text { years) }\end{array}$ & & $\begin{array}{l}\text { highest values }(>5.5 \mu \mathrm{M} / \mathrm{min}) \text { at day } \\
2-5 \text { after TBI }\end{array}$ \\
\hline
\end{tabular}

Contd... 
Table 1: Contd...

\begin{tabular}{|c|c|c|c|c|c|}
\hline Clinical study & Biomarker & Time points & $\begin{array}{l}\text { Subjects, group } \\
\text { size, and age }\end{array}$ & Matrix/levels & Results \\
\hline$\overline{\mathrm{TBI}}$ (severe) ${ }^{[77]}$ & Caspase-3 & $\begin{array}{l}1,2,3,5,7 \text {, and } \\
10 \text { days }\end{array}$ & $\begin{array}{l}14 \text { patients } \\
\text { (5-69 years, mean } \\
\text { age } 25.3 \pm 15.4 \text { years) }\end{array}$ & CSF & $\begin{array}{l}\text { Caspase-3 and Bcl-2 activities } \\
\text { significantly increased in CSF of } \\
\text { patients } \\
\text { Significant correlation of caspase-3 } \\
\text { associated with increased ICP and } \\
\text { cerebral perfusion pressure } \\
\text { Significant association between } \\
\text { caspase-3 and soluble Fas on day } \\
5 \text { after TBI }\end{array}$ \\
\hline TBI (severe) $)^{[198]}$ & $\begin{array}{l}\text { Caspase-3 } \\
\text { (activated) }\end{array}$ & 1 day & $\begin{array}{l}112 \text { patients } \\
81 \text { survivors } \\
\text { (median age } \\
46 \text { years, IQRs } \\
27-60 \text { years) } \\
31 \text { nonsurvivors } \\
\text { (median age } \\
63 \text { years IQRs } \\
53-75 \text { years) }\end{array}$ & Serum & $\begin{array}{l}\text { Multiple logistic regression analysis } \\
\text { showed that serum caspase- } 3 \\
\text { levels }>0.20 \mathrm{ng} / \mathrm{mL} \text { were associated } \\
\text { with mortality at } 30 \text { days in TBI } \\
\text { patients controlling for Marshall } \\
\text { CT classification, age and GCS } \\
(O R=7.99 ; 95 \% \mathrm{Cl}=2.116-36.744 \text {; } \\
P=0.001)\end{array}$ \\
\hline$\left.\mathrm{TB}\right|^{[148]}$ & Caspase-7 & Acute & $\begin{array}{l}16 \text { patients (mean } \\
\text { age } 40.4 \pm 10.1 \text { years) } \\
6 \text { controls (mean age } \\
52.2 \pm 21.3 \text { years) }\end{array}$ & $\begin{array}{l}\text { Brain tissue } \\
\text { (postmortem) } \\
\text { (Western blot and } \\
\text { IHC) }\end{array}$ & $\begin{array}{l}\text { Significant increases in } \\
\text { pro-caspase- } 7 \text { and } 20 \mathrm{kD} \\
\text { proteolytic fragment in TBI patients } \\
\text { compared to controls } \\
\text { Caspase- } 7 \text { expression included } \\
\text { astrocytes, neurons, and possibly } \\
\text { other glial cell types and infiltrated } \\
\text { inflammatory cells }\end{array}$ \\
\hline TBI (severe) ${ }^{[78]}$ & Caspase-8 & $\begin{array}{l}\text { Acute phase of } \\
\text { TBI }\end{array}$ & $\begin{array}{l}17 \text { patients } \\
\text { (16-64 years, mean } \\
\text { age } 40 \pm 17 \text { years) } \\
6 \text { controls } \\
\text { (16-77 years, mean } \\
\text { age } 52 \pm 22 \text { years) }\end{array}$ & $\begin{array}{l}\text { Brain tissue (TBI, } \\
\text { surgically removed) } \\
\text { Brain tissue (control, } \\
\text { postmortem) }\end{array}$ & $\begin{array}{l}\text { Significant increases in caspase- } 8 \\
\text { mRNA and protein in TBI patients } \\
\text { as compared to controls } \\
\text { Caspase- } 8 \text { protein was } \\
\text { predominately expressed in } \\
\text { neurons } \\
\text { Proteolytic } 20 \mathrm{kDa} \text { fragments of } \\
\text { caspase- } 8 \text { were detected only in } \\
\text { TBI patients } \\
\text { Association of caspase- } 8 \text { with Fas } \\
\text { in TBI patients }\end{array}$ \\
\hline TBI (severe) $)^{[152]}$ & Caspase-9 & $\begin{array}{l}\text { 2-26 } \mathrm{h} \text { (catheter } \\
\text { placement) } 24, \\
48 \text { and } 72 \mathrm{~h} \\
\text { (intervals) }\end{array}$ & $\begin{array}{l}9 \text { patients } \\
\text { (18-62 years; median } \\
\text { age, } 40 \text { years) } \\
5 \text { controls } \\
\text { (orthopedic) }\end{array}$ & CSF (ELISA) & $\begin{array}{l}\text { Cytochrome c was detected in } \\
18(51.4 \%) \text { samples }(0.44 \pm 0.632 \text {, } \\
\text { mean } \pm \text { SD) } \\
\text { Activated caspase- } 9 \text { was } \\
\text { detected in } 10(28.6 \%) \text { samples } \\
(0.28 \pm 0.39 \mathrm{ng} / \mathrm{mL}, \text { mean } \pm S D) \\
\text { Control CSF samples had no } \\
\text { detectable levels of either marker } \\
\text { Activated caspase- } 9 \text { shows weak } \\
\text { correlation with poor neurological } \\
\text { outcome }\end{array}$ \\
\hline TBI (severe) $)^{[199]}$ & CCCK-18 & Admission & $\begin{array}{l}100 \text { patients } \\
73 \text { survivors } \\
\text { (median age } \\
66 \text { years IQRs } \\
45-76 \text { years) } \\
27 \text { nonsurvivors } \\
\text { (median age } \\
47 \text { years IQRs } \\
32-67 \text { years) }\end{array}$ & Serum $>201 \mathrm{u} / \mathrm{L}$ & $\begin{array}{l}\text { CCCK-18 levels are associated with } \\
\text { 30-day mortality }\end{array}$ \\
\hline
\end{tabular}


Table 1: Contd...

\begin{tabular}{|c|c|c|c|c|c|}
\hline Clinical study & Biomarker & Time points & $\begin{array}{l}\text { Subjects, group } \\
\text { size, and age }\end{array}$ & Matrix/levels & Results \\
\hline TBI (severe) $)^{[200]}$ & SBDP120 & Acute & $\begin{array}{l}12 \text { TBI patients } \\
9 \text { control \#1 (SAH, } \\
\text { IVH, brain tumor) } \\
5 \text { control \#2 } \\
\text { (diagnostic } \\
\text { lumbar puncture) } \\
\text { (18-70 years) }\end{array}$ & CSF (ventricular) & $\begin{array}{l}\text { Nonerythroid lll-spectrin and } \\
\text { SBDPs occurred more frequently } \\
\text { and their level was significantly } \\
\text { higher in the CSF of TBI patients } \\
\text { than in other pathological conditions } \\
\text { associated with raised ICP }\end{array}$ \\
\hline TBI (severe) $)^{[201]}$ & SBDP120 & $\begin{array}{l}6,12,24,48,72 \\
96, \text { and } 120 \mathrm{~h}\end{array}$ & $\begin{array}{l}41 \text { patients } \\
\text { (18-67 years, mean } \\
\text { age } 38 \text { years) }\end{array}$ & CSF & $\begin{array}{l}\text { Calpain and caspase-3 mediated } \\
\text { SBDP levels in CSF were } \\
\text { significantly increased in TBI } \\
\text { patients at several time points } \\
\text { after injury as compared to } \\
\text { control subjects. The time course } \\
\text { of calpain-mediated SBDP150 } \\
\text { and SBDP145 differed from } \\
\text { that of caspase-3 mediated } \\
\text { SBDP120 during the postinjury } \\
\text { period examined. Mean SBDP } \\
\text { densitometry values measured } \\
\text { early after injury correlated with } \\
\text { severity of injury, CT findings, and } \\
\text { 6-month outcome }\end{array}$ \\
\hline TBI (severe) $)^{[202]}$ & SBDP120 & $\begin{array}{l}\text { Admission and } \\
\text { every } 6 \mathrm{~h} \text { up to } \\
7 \text { days }\end{array}$ & $\begin{array}{l}40 \text { patients } \\
\text { (18-82 years, mean } \\
\text { age } 41.5 \pm 3.17 \text { years) } \\
24 \text { controls } \\
\text { (23-83 years, mean } \\
\text { age } 56.2 \pm 4.42 \text { years) }\end{array}$ & $\mathrm{CSF}>17.55 \mathrm{ng} / \mathrm{mL}$ & $\begin{array}{l}\text { SBDP120 release was more } \\
\text { accurate } 24 \mathrm{~h} \text { after injury. Within } \\
24 \mathrm{~h} \text { after injury, SBDP145 CSF } \\
\text { concentrations significantly } \\
\text { correlated with GCS scores, while } \\
\text { SBDP120 levels correlated with } \\
\text { age. SBDP levels were significantly } \\
\text { higher in patients who died than } \\
\text { in those who survived. SBDP145 } \\
\text { levels }(>6 \mathrm{ng} / \mathrm{mL}) \text { and SBDP120 } \\
\text { levels }(>17.55 \mathrm{ng} / \mathrm{mL}) \text { strongly } \\
\text { predicted death }\end{array}$ \\
\hline $\begin{array}{l}\text { TBI (sport } \\
\text { concussion) }^{[127]}\end{array}$ & $\begin{array}{l}\text { Caspase - } \\
\text { cleaved tau }\end{array}$ & $\begin{array}{l}1,12,36 \text { and } \\
144 \mathrm{~h}\end{array}$ & $\begin{array}{l}288 \text { adult ice } \\
\text { hockey players } \\
\text { ( } 35 \text { concussion) }\end{array}$ & Serum & $\begin{array}{l}\text { Serum levels of caspase - cleaved } \\
\text { tau were significantly higher in } \\
\text { postconcussion samples compared } \\
\text { with preseason }\end{array}$ \\
\hline
\end{tabular}

IHC: Immunohistochemistry, PARP: Poly (ADP-ribose) polymerase, TUNEL: Transferase-mediated dUTP-digoxigenin nick end-labeling, p-JNK: Phosphorylated c-Jun $\mathrm{N}$-terminal kinases, tPA: Tissue plasminogen activator, TNF- $\alpha$ : Tumor necrosis factor-alpha, qRT-PCR: Quantitative reverse transcription polymerase chain reaction, PKCS: Protein kinase catalytic subunit, MMP: Metalloproteinase, NIHSS: National Institute Health Stroke Scale, AD: Alzheimer's disease, SBDPs: Spectrin breakdown products, N/A: Not available, CCCK: Caspase-cleaved cytokeratin, IL-1ß: Interleukin 1 beta, GOS: Glasgow Outcome Scale, WFNS: World Federation of Neurological Surgeon, CSF: Cerebrospinal fluid, SAH: Subarachnoid hemorrhage, TBI: Traumatic brain injury, GCS: Glasgow Coma Scale, NF-кB: Nuclear factor kappa B, OR: Odds ratio, CT: Computed tomography, SD: Standard deviation, IQRs: Interquartile ranges, ICP: Intracranial pressure, CI: Confidence interval, IVH: Intraventricular hemorrhage, RAGE: Receptor for advanced glycation end products, MAP-2: microtubule associated protein-2

after SAH independently of age. ${ }^{[192]}$ Lorente et al. have recently reported that increased serum levels of caspase- 3 are associated with increased mortality in patients with severe TBI. ${ }^{[199]}$

\section{Caspase-3-mediated Pathways in Developing Brain following Traumatic Brain Injury and Hypoxic-ischemic Brain Injuries}

It is well recognized that neuronal apoptosis in the developing brain is a physiological process controlled within normal CNS function which involves activation of Bcl-2-mediated upregulation of caspases 9 and $3 .{ }^{[50,53]}$ Thus, the pediatric patient population, especially neonates, might be more vulnerable to apoptotic cell death than adults. ${ }^{[52]}$ Clinical studies in pediatric stroke (e.g., perinatal hypoxic-ischemic brain injury), ${ }^{[186,187]}$ neurological injury associated with congenital heart disease surgery, ${ }^{[189]}$ and $\mathrm{TBI}^{[76,160]}$ have demonstrated increases in the caspase- 3 and other apoptotic markers (e.g., TUNEL, Bcl-2, Bcl-x, cytochrome c) including those associated with caspase-3 activity such as SBDP120 and fractin, a caspase-specific actin cleavage product, in brain injured patients compared to controls. These data suggest that normal apoptotic pathways involved in CNS development are disrupted following ischemic and traumatic brain injuries that may affect long-term neurological outcome. ${ }^{[50,51]}$ Askalan et al. have also suggested that cell death in the penumbra 
of subacute infarcts following focal brain ischemia in children is partially caspase- 3 independent and may be attributed to nitric oxide. ${ }^{[188]}$ Several preclinical studies, using multiple animal models of neonatal brain injury, have documented involvement of apoptosis in neural cell death and potentially protective effects of selective caspase-3 inhibition to reduce neonatal hypoxic-ischemic brain injury. ${ }^{[207-214]}$ However, a study using genetically modified mice lacking caspase-3 gene (Casp3/-mice) had shown worsened outcomes in these mice after neonatal hypoxic-ischemic brain injury compared to wild-type controls, suggesting a protective role of caspase- 3 in the developing brain. ${ }^{[215]}$ In contrast, improved outcomes following ischemia-reperfusion brain injury have been reported in adult Casp3/-mice. ${ }^{[216]}$ Taken together, the aforementioned preclinical studies in wild-type rodent species and caspase- 3 knockout mice suggest complex and differential roles of caspase- 3 in adult and developing brain.

\section{Caspase-cleaved Products as Biomarkers of Brain Apoptosis following Stroke and Traumatic Brain Injury}

\section{Caspase-cleaved cytokeratin-18}

The protein cytokeratin-18, an intermediate filament cytoskeletal protein primarily expressed in epithelial cells, is a well-recognized caspase substrate that is cleaved during epithelial cell apoptosis resulting in the production and release into circulation of its major cleavage fragment CCCK-18. ${ }^{[217]}$ A pilot study by Lorente et al. has shown that serum levels of CCCK-18 are associated with mortality in patients with severe TBI. ${ }^{[199]}$ Two recent studies have also demonstrated that blood levels of CCCK-18 were increased in patients with intracerebral hemorrhage ${ }^{[190]}$ and aneurysmal $\mathrm{SAH},{ }^{[193]}$ and the increased levels were associated with poor short- and long-term neurological outcomes and mortality. A study by $\mathrm{Gu}$ et al. has also shown that increased serum CCCK-18 levels following intracerebral hemorrhage were associated with neurological deficits and hematoma volume. ${ }^{[190]}$

\section{Calpain- and caspase-mediated spectrin breakdown products}

$\alpha$ II-Spectrin is a major axonal cytoskeletal protein and a major substrate for both calpain and caspase-3 proteases following brain injuries. Degradation of $\alpha \mathrm{II}-$ spectrin is an important component of necrotic and apoptotic cell death, respectively. ${ }^{[218]}$ Moreover, $\alpha$ II-spectrin cleavage by caspase and caspase proteases produce signature cleavage products including SBDP120 and $145 \mathrm{kDa}$ and $150 \mathrm{kDa} \alpha \mathrm{II}-\mathrm{SBDP}$ (SBDP145 and SBDP150) resulted primarily from caspase-3-mediated (apoptosis) and calpain-mediated (necrosis) proteolysis, respectively. ${ }^{[21,220]}$ However, there is evidence that SBDP150 might be associated with activities of both calpain and caspase-3 proteases. ${ }^{[221]}$ Moreover, a recent experimental study using in vitro primary rat cerebrocortical cell cultures under apoptotic, necrotic, and excitotoxic conditions together with an in vivo rat TBI model suggests that breakdown of $\beta I I-s p e c t r i n$, another important neuronal cytoskeletal protein, by caspase- 3 and calpain-mediated proteolysis, contributes to cell death following brain injuries and that protease-specific signature $\beta$ II-SBDPs may serve as biomarkers indicative of neuronal cell death mechanism. ${ }^{[222]}$

Experimental data obtained in animal models demonstrated an increase in the levels of both caspase- 3 and calpain-specific SBDPs in brain and CSF after experimental ischemia ${ }^{[223-225]}$ and preclinical models of TBI. ${ }^{[130]}$ Interestingly, increased levels of SBDP120 after experimental TBI were observed in the triple transgenic AD mice (3xTg-AD) compared to wild-type controls of the same background. ${ }^{[131]}$ Clinical studies in severe TBI have confirmed utility of SBDP120 as a sensitive biomarker of caspase-3 activation exclusively associated with apoptotic cell death. ${ }^{[129]}$ Other studies have confirmed the utility of SBDP145 and SBDP150 as highly useful biomarkers of calpain activation primarily associated with necrosis. ${ }^{[218]}$ In addition, both caspase-3 and calpain-specific SBDPs (i.e., SBDP120, SBDP145, and SBDP150) are currently thought to be biomarkers associated with an increased intracranial pressure. ${ }^{[129,226]}$

In patients with TBI, increases in CSF concentrations of different SBDPs were correlated with a severe TBI diagnosis. The temporal profiles of SBDP145 and SBDP120 suggested that neuronal cell death within the first $72 \mathrm{~h}$ is mostly due to necrosis, whereas delayed cell death after $72 \mathrm{~h}$ after brain trauma is primarily due to apoptosis. ${ }^{[129,201]}$ Differential temporal increases in the serum levels of SBDP120 and SBDP150 have been reported in infants with congenital heart disease following open heart surgery, suggesting that SBDPs could be developed as biomarkers for brain necrosis and apoptosis. ${ }^{[189]}$ Significant increases in SBDP120 and SBDP150 levels were shown in the CSF of SAH patients, and these SBDPs, when used in a biomarker panel, were significantly correlated with brain infarction, cerebral vasospasm, and generally poor outcomes. ${ }^{[194,227]}$

\section{Caspase-cleaved tau}

Tau is a structural protein that belongs to the neuron-specific Type II microtubule-associated protein family and is predominantly expressed in neurons and to a lesser extent in astrocytes and oligodendrocytes. Pathological formation of insoluble tau aggregates is implicated in the etiopathology of a class of neurodegenerative diseases, including CTE, AD, and PD, referred to also as tauopathies. ${ }^{[228]}$ The detailed molecular mechanisms of the formation of tau aggregates and their 
roles in progression of neurodegenerative disorders are still not completely understood. Hypothetical mechanisms of tau aggregate formation include its abnormal modification by hyperphosphorylation ${ }^{[229,230]}$ and caspase-3-mediated cleavage. ${ }^{[59,112]}$

CSF and serum levels of total tau and its hyperphosphorylated form have long been considered as promising biomarkers of brain disorders primarily associated with neurodegeneration characteristic of chronic neurodegenerative disease $\mathrm{e}^{[231,232]}$ and acute brain injuries such as ischemic and hemorrhagic strokes and TBI. ${ }^{[233-240]}$

In ischemic stroke patients, CSF and blood tau protein levels transiently increase after $24 \mathrm{~h}$ within the $1^{\text {st }}$ week of symptom onset and returned to control levels after 3-5 months. The acute increases in tau concentrations in samples collected between 5 and 10 days after stroke onset were associated with clinical stroke severity, stroke outcomes, and prognosis. ${ }^{[233-235,241,242]}$

Clinical data obtained in hemorrhagic stroke and TBI patients showed that increases in CSF and serum tau levels are detectable in samples collected at admission, ${ }^{[237,240,243]}$ suggesting that following intracerebral hemorrhage and TBI, the increases in tau concentration appeared at an earlier time point after injury than the increases in tau observed in the ischemic stroke where tau was undetectable in most samples at $24 \mathrm{~h}$ after symptom onset. ${ }^{[242]}$ Acute serum and CSF tau protein concentrations in TBI patients are correlated with short- and long-term outcomes. ${ }^{[237,240]}$ Similarly, serum concentrations of tau in samples collected from hemorrhagic stroke patients at admission were predictive of mortality and poor 3-month neurological outcomes. ${ }^{[243]}$ Significant increases in the serum concentration of caspasecleaved tau were observed in ischemic stroke patients with poor outcomes for patients at day 7 after stroke onset compared to the caspasecleaved tau concentrations in these patients measured at admission and compared to the caspasecleaved tau concentrations in patients with favorable outcomes and controls. ${ }^{[184]}$ In addition, increased levels of caspase-3-cleaved tau is a candidate biomarker associated with increased intracranial pressure following TBI. ${ }^{[226]}$ Significant increases in serum concentrations of caspasecleaved tau were observed in athletes after concussion as compared to the caspasecleaved tau concentrations in preseason samples. ${ }^{[127]}$

\section{Clinical Implication of Biomarkers Related to Caspase-3-mediated Pathways in Acute Brain Injuries and Chronic Degeneration}

Apoptosis is a common feature of acute brain injuries and many neurological disorders and neurodegenerative disorders associated with inflammatory and neurovascular pathologies. Apoptosis is involved in the irregular accumulation of different isoforms of tau, blood-brain barrier dysfunction, and abnormal angiogenesis. ${ }^{[39,106-108]}$ Caspase-3 upregulation in neuronal, glial, and infiltrating inflammatory cells contributes to the overall pathology following stroke and TBI in humans. Caspase-3-mediated apoptosis plays a key role in cleavage of cytoskeletal proteins ${ }^{[59]}$ that can further contribute to chronic axonal and microvascular damage. ${ }^{[153,244,245]}$ Clinical and experimental data indicate that the increased levels of a specific caspase-3 proteolytic product, SBDP120, are associated axonal damage following TBI pathology in humans, and these processes are accelerated in AD-like animal models suggesting a possible link between mechanisms involved in chronic axonal damage in these disorders..$^{[129,131]}$

Increased levels of several tau isoforms including hyperphosphorylated and caspase-3-cleaved tau are considered hallmarks of neurodegeneration. ${ }^{[123,124]}$ The presence of caspase-3-cleaved in neurofibrillary tangles is one of the earliest events in the tangle pathology of $\mathrm{AD}$, leading to formation of amyloid plaques. ${ }^{[112,121,122]}$ Thus, tau isoforms are considered to be one of the earliest biomarkers of AD. ${ }^{[106,120,121,125]}$ Increased levels of caspase-cleaved tau were observed in brain extracts of CTE patients ${ }^{[126]}$ and in serum of both TBI, stroke, and patients with $\mathrm{AD} \cdot{ }^{[127,128,184]}$ Thus, abnormal tau processing following stroke and $\mathrm{TB} \mathrm{I}^{[127,184]}$ might be an initial step triggering formation of fibrillary tangles and amyloid plaques that are commonly observed in $\mathrm{AD}$ and other neurodegenerative disorders. ${ }^{[106,119,120]}$

\section{Conclusion}

The current data provide strong experimental and clinical evidence that activation of caspase-3 following acute brain injuries including ischemic and hemorrhagic stroke and TBI is involved in the etiopathology of these disorders by inducing neuronal and glial cell death and degradation of cytoskeletal proteins that might affect neuronal and microvascular function and further trigger pathological processes underlying the development of chronic neurodegenerative diseases. The levels of biomarkers associated with caspase- 3 activity in CSF and peripheral blood, including the levels of caspase-3 and other selected caspases such as products of caspase-3-mediated cleavage of cell-specific epithelial (e.g., CCCK-18) and neuronal (e.g., SBDP120, caspase-3-cleaved tau) proteins, might provide valuable information for assessment of injury severity and mechanism and predict clinical outcomes. In light of the critical role of cleaved caspase- 3 in the accumulation of caspase-3-cleaved tau, an early marker of neurodegenerative processes, the caspase-3-mediated pathway may be a promising target 
for development of novel therapeutic strategies for the treatment of stroke and TBI.

\section{Financial support and sponsorship \\ Nil.}

\section{Conflicts of interest}

Ronald L. Hayes owns stock, receives compensation from and is an executive officer of Banyan Biomarkers, Inc., and, as such, may benefit financially as a result of the outcomes of this research or work reported in this publication.

\section{References}

1. Hyder AA, Wunderlich CA, Puvanachandra P, Gururaj G, Kobusingye OC. The impact of traumatic brain injuries: A global perspective. NeuroRehabilitation 2007;22:341-53.

2. Rosamond W, Flegal K, Furie K, Go A, Greenlund K, Haase N, et al. Heart disease and stroke statistics-2008 update: A report from the American Heart Association Statistics Committee and Stroke Statistics Subcommittee. Circulation 2008;117:e25-146.

3. Kochanek KD, Murphy SL, Xu J, Arias E. Mortality in the United States, 2013. NCHS Data Brief 2014;178:1-8.

4. Mozaffarian D, Benjamin EJ, Go AS, Arnett DK, Blaha MJ, Cushman M, et al. Heart disease and stroke statistics-2015 update: A report from the American Heart Association. Circulation 2015;131:e29-322.

5. GBD Mortality and Causes of Death Collaborators. Global, regional, and national age-sex specific all-cause and cause-specific mortality for 240 causes of death, 1990-2013: A systematic analysis for the Global Burden of Disease Study 2013. Lancet 2015;385:117-71.

6. Feigin VL, Forouzanfar MH, Krishnamurthi R, Mensah GA, Connor M, Bennett DA, et al. Global and regional burden of stroke during 1990-2010: Findings from the Global Burden of Disease Study 2010. Lancet 2014;383:245-54.

7. Johnston SC, Mendis S, Mathers CD. Global variation in stroke burden and mortality: Estimates from monitoring, surveillance, and modelling. Lancet Neurol 2009;8:345-54.

8. Coronado VG, Xu L, Basavaraju SV, McGuire LC, Wald MM, Faul MD, et al. Surveillance for traumatic brain injury-related deaths - United States, 1997-2007. MMWR Surveill Summ 2011;60:1-32.

9. Thurman DJ, Alverson C, Dunn KA, Guerrero J, Sniezek JE. Traumatic brain injury in the United States: A public health perspective. J Head Trauma Rehabil 1999;14:602-15.

10. Langlois JA, Rutland-Brown W, Wald MM. The epidemiology and impact of traumatic brain injury: A brief overview. J Head Trauma Rehabil 2006;21:375-8.

11. Faul M, Coronado V. Epidemiology of traumatic brain injury. Handb Clin Neurol 2015;127:3-13.

12. Pearson WS, Sugerman DE, McGuire LC, Coronado VG. Emergency department visits for traumatic brain injury in older adults in the United States: 2006-08. West J Emerg Med 2012;13:289-93.

13. Adams JH, Jennett B, Murray LS, Teasdale GM, Gennarelli TA, Graham DI. Neuropathological findings in disabled survivors of a head injury. J Neurotrauma 2011;28:701-9.

14. Taylor \& Francis Group. Translational Research in Traumatic Brain Injury. Boca Raton, FL: Taylor \& Francis Group, LLC; 2016.

15. The World Health Organization MONICA Project (monitoring trends and determinants in cardiovascular disease): A major international collaboration. WHO MONICA Project Principal Investigators. J Clin Epidemiol 1988;41:105-14.

16. Easton JD, Saver JL, Albers GW, Alberts MJ, Chaturvedi S, Feldmann E, et al. Definition and evaluation of transient ischemic attack: A scientific statement for healthcare professionals from the American Heart Association/American Stroke Association Stroke Council; Council on Cardiovascular Surgery and Anesthesia; Council on Cardiovascular Radiology and Intervention; Council on Cardiovascular Nursing; and the Interdisciplinary Council on Peripheral Vascular Disease. The American Academy of Neurology affirms the value of this statement as an educational tool for neurologists. Stroke 2009;40:2276-93.

17. Feigin VL, Lawes CM, Bennett DA, Anderson CS. Stroke epidemiology: A review of population-based studies of incidence, prevalence, and case-fatality in the late $20^{\text {th }}$ century. Lancet Neurol 2003;2:43-53.

18. Johnston SC, Selvin S, Gress DR. The burden, trends, and demographics of mortality from subarachnoid hemorrhage. Neurology 1998;50:1413-8.

19. Feigin VL, Rinkel GJ, Lawes CM, Algra A, Bennett DA, van Gijn J, et al. Risk factors for subarachnoid hemorrhage: An updated systematic review of epidemiological studies. Stroke 2005;36:2773-80.

20. Glushakov AV, Glushakova OY, Doré S, Carney PR, Hayes RL. Animal models of posttraumatic seizures and epilepsy. Methods Mol Biol 2016;1462:481-519.

21. Daneshvar DH, Goldstein LE, Kiernan PT, Stein TD, McKee AC. Post-traumatic neurodegeneration and chronic traumatic encephalopathy. Mol Cell Neurosci 2015;66(Pt B):81-90.

22. Taylor KM, Saint-Hilaire MH, Sudarsky L, Simon DK, Hersh B, Sparrow D, et al. Head injury at early ages is associated with risk of Parkinson's disease. Parkinsonism Relat Disord 2016;23:57-61.

23. Povlishock JT, Katz DI. Update of neuropathology and neurological recovery after traumatic brain injury. J Head Trauma Rehabil 2005;20:76-94.

24. Hong YT, Veenith T, Dewar D, Outtrim JG, Mani V, Williams C, et al. Amyloid imaging with carbon 11-labeled Pittsburgh compound B for traumatic brain injury. JAMA Neurol 2014;71:23-31.

25. Lucke-Wold BP, Nguyen L, Turner RC, Logsdon AF, Chen YW, Smith KE, et al. Traumatic brain injury and epilepsy: Underlying mechanisms leading to seizure. Seizure 2015;33:13-23.

26. White L, Petrovitch H, Hardman J, Nelson J, Davis DG, Ross GW, et al. Cerebrovascular pathology and dementia in autopsied Honolulu-Asia Aging Study participants. Ann N Y Acad Sci 2002;977:9-23.

27. Petrovitch H, Ross GW, Steinhorn SC, Abbott RD, Markesbery W, Davis D, et al. ADlesions and infarcts in demented and non-demented Japanese-American men. Ann Neurol 2005;57:98-103.

28. Toledo JB, Arnold SE, Raible K, Brettschneider J, Xie SX, Grossman $\mathrm{M}$, et al. Contribution of cerebrovascular disease in autopsy confirmed neurodegenerative disease cases in the National Alzheimer's Coordinating Centre. Brain 2013;136(Pt 9):2697-706.

29. Luchsinger JA, Tang MX, Stern Y, Shea S, Mayeux R. Diabetes mellitus and risk of Alzheimer's disease and dementia with stroke in a multiethnic cohort. Am J Epidemiol 2001;154:635-41.

30. Qi JP, Wu H, Yang Y, Wang DD, Chen YX, Gu YH, et al. Cerebral ischemia and Alzheimer's disease: The expression of amyloid-beta and apolipoprotein E in human hippocampus. J Alzheimers Dis 2007;12:335-41.

31. Arvanitakis Z, Capuano AW, Leurgans SE, Bennett DA, Schneider JA. Relation of cerebral vessel disease to Alzheimer's disease dementia and cognitive function in elderly people: A cross-sectional study. Lancet Neurol 2016;15:934-943.

32. Attems J, Jellinger KA. The overlap between vascular disease and Alzheimer's disease - Lessons from pathology. BMC Med 2014;12:206. 
33. Jendroska K, Poewe W, Daniel SE, Pluess J, Iwerssen-Schmidt H, Paulsen $\mathrm{J}$, et al. Ischemic stress induces deposition of amyloid beta immunoreactivity in human brain. Acta Neuropathol 1995;90:461-6.

34. Koistinaho M, Koistinaho J. Interactions between Alzheimer's disease and cerebral ischemia - Focus on inflammation. Brain Res Brain Res Rev 2005;48:240-50.

35. Yuan J, Yankner BA. Apoptosis in the nervous system. Nature 2000;407:802-9.

36. Wyllie AH, Kerr JF, Currie AR. Cell death: The significance of apoptosis. Int Rev Cytol 1980;68:251-306.

37. Kanduc D, Mittelman A, Serpico R, Sinigaglia E, Sinha AA, Natale $C$, et al. Cell death: Apoptosis versus necrosis (review). Int J Oncol 2002;21:165-70.

38. Martin LJ. Neuronal cell death in nervous system development, disease, and injury (Review). Int J Mol Med 2001;7:455-78.

39. Mattson MP. Apoptosis in neurodegenerative disorders. Nat Rev Mol Cell Biol 2000;1:120-9.

40. Ribe EM, Serrano-Saiz E, Akpan N, Troy CM. Mechanisms of neuronal death in disease: Defining the models and the players. Biochem J 2008;415:165-82.

41. Rossi F, Cattaneo E. Opinion: Neural stem cell therapy for neurological diseases: Dreams and reality. Nat Rev Neurosci 2002;3:401-9.

42. Kuhn HG, Palmer TD, Fuchs E. Adult neurogenesis: A compensatory mechanism for neuronal damage. Eur Arch Psychiatry Clin Neurosci 2001;251:152-8.

43. Eriksson PS, Perfilieva E, Björk-Eriksson T, Alborn AM, Nordborg C, Peterson DA, et al. Neurogenesis in the adult human hippocampus. Nat Med 1998;4:1313-7.

44. Liu J, Solway K, Messing RO, Sharp FR. Increased neurogenesis in the dentate gyrus after transient global ischemia in gerbils. J Neurosci 1998;18:7768-78.

45. Akpan N, Troy CM. Caspase inhibitors: Prospective therapies for stroke. Neuroscientist 2013;19:129-36.

46. Chan SL, Mattson MP. Caspase and calpain substrates: Roles in synaptic plasticity and cell death. J Neurosci Res 1999;58:167-90.

47. Oppenheim RW. Cell death during development of the nervous system. Annu Rev Neurosci 1991;14:453-501.

48. D'Amelio M, Cavallucci V, Cecconi F. Neuronal caspase-3 signaling: Not only cell death. Cell Death Differ 2010;17:1104-14.

49. Troy CM, Akpan N, Jean YY. Regulation of caspases in the nervous system implications for functions in health and disease. Prog Mol Biol Transl Sci 2011;99:265-305.

50. Roth KA, D'Sa C. Apoptosis and brain development. Ment Retard Dev Disabil Res Rev 2001;7:261-6.

51. Raff MC, Barres BA, Burne JF, Coles HS, Ishizaki Y, Jacobson MD. Programmed cell death and the control of cell survival: Lessons from the nervous system. Science 1993;262:695-700.

52. Ferriero DM, Miller SP. Imaging selective vulnerability in the developing nervous system. J Anat 2010;217:429-35.

53. Zaidi AU, D'Sa-Eipper C, Brenner J, Kuida K, Zheng TS, Flavell RA, et al. Bcl-X(L)-caspase-9 interactions in the developing nervous system: Evidence for multiple death pathways. J Neurosci 2001;21:169-75.

54. Yuan JY, Horvitz HR. The Caenorhabditis elegans genes ced-3 and ced-4 act cell autonomously to cause programmed cell death. Dev Biol 1990;138:33-41.

55. Horvitz HR. Genetic control of programmed cell death in the nematode Caenorhabditis elegans. Cancer Res 1999;59 7 Suppl: 1701s-6s.

56. Hengartner MO, Horvitz HR. Programmed cell death in Caenorhabditis elegans. Curr Opin Genet Dev 1994;4:581-6.

57. Yuan J, Shaham S, Ledoux S, Ellis HM, Horvitz HR. The C. elegans cell death gene ced-3 encodes a protein similar to mammalian interleukin-1 beta-converting enzyme. Cell 1993;75:641-52.
58. Miura M, Zhu H, Rotello R, Hartwieg EA, Yuan J. Induction of apoptosis in fibroblasts by IL-1 beta-converting enzyme, a mammalian homolog of the C. elegans cell death gene ced-3. Cell 1993;75:653-60.

59. Crawford ED, Wells JA. Caspase substrates and cellular remodeling. Annu Rev Biochem 2011;80:1055-87.

60. Eldadah BA, Faden AI. Caspase pathways, neuronal apoptosis, and CNS injury. J Neurotrauma 2000;17:811-29.

61. Friedlander RM. Apoptosis and caspases in neurodegenerative diseases. N Engl J Med 2003;348:1365-75.

62. Cohen GM. Caspases: The executioners of apoptosis. Biochem J 1997;326(Pt 1):1-16.

63. Hengartner MO. The biochemistry of apoptosis. Nature 2000;407:770-6.

64. Shi Y. Mechanisms of caspase activation and inhibition during apoptosis. Mol Cell 2002;9:459-70.

65. Riedl SJ, Shi Y. Molecular mechanisms of caspase regulation during apoptosis. Nat Rev Mol Cell Biol 2004;5:897-907.

66. Liu X, Zou H, Slaughter C, Wang X. DFF, a heterodimeric protein that functions downstream of caspase-3 to trigger DNA fragmentation during apoptosis. Cell 1997;89:175-84.

67. Sakahira H, Enari M, Nagata S. Cleavage of CAD inhibitor in CAD activation and DNA degradation during apoptosis. Nature 1998;391:96-9.

68. Enari M, Sakahira H, Yokoyama H, Okawa K, Iwamatsu A, Nagata S. A caspase-activated DNase that degrades DNA during apoptosis, and its inhibitor ICAD. Nature 1998;391:43-50.

69. Liu X, Li P, Widlak P, Zou H, Luo X, Garrard WT, et al. The 40-kDa subunit of DNA fragmentation factor induces DNA fragmentation and chromatin condensation during apoptosis. Proc Natl Acad Sci U S A 1998;95:8461-6.

70. Pellegrini M, Strasser A. A portrait of the Bcl-2 protein family: Life, death, and the whole picture. J Clin Immunol 1999;19:365-77.

71. Gillies LA, Kuwana T. Apoptosis regulation at the mitochondrial outer membrane. J Cell Biochem 2014;115:632-40.

72. Yuan S, Yu X, Topf M, Ludtke SJ, Wang X, Akey CW. Structure of an apoptosome-procaspase-9 CARD complex. Structure 2010;18:571-83.

73. Ashkenazi A, Dixit VM. Death receptors: Signaling and modulation. Science 1998;281:1305-8.

74. Sairanen T, Szepesi R, Karjalainen-Lindsberg ML, Saksi J, Paetau A, Lindsberg PJ. Neuronal caspase-3 and PARP-1 correlate differentially with apoptosis and necrosis in ischemic human stroke. Acta Neuropathol 2009;118:541-52.

75. Yew DT, Ping Li W, Liu WK. Fas and activated caspase 8 in normal, Alzheimer and multiple infarct brains. Neurosci Lett 2004;367:113-7.

76. Satchell MA, Lai Y, Kochanek PM, Wisniewski SR, Fink EL, Siedberg NA, et al. Cytochrome c, a biomarker of apoptosis, is increased in cerebrospinal fluid from infants with inflicted brain injury from child abuse. J Cereb Blood Flow Metab 2005;25:919-27.

77. Uzan M, Erman H, Tanriverdi T, Sanus GZ, Kafadar A, Uzun H. Evaluation of apoptosis in cerebrospinal fluid of patients with severe head injury. Acta Neurochir (Wien) 2006;148:1157-64.

78. Zhang X, Graham SH, Kochanek PM, Marion DW, Nathaniel PD, Watkins SC, et al. Caspase-8 expression and proteolysis in human brain after severe head injury. FASEB J 2003;17:1367-9.

79. Phanithi PB, Yoshida Y, Santana A, Su M, Kawamura S, Yasui N. Mild hypothermia mitigates post-ischemic neuronal death following focal cerebral ischemia in rat brain: Immunohistochemical study of Fas, caspase- 3 and TUNEL. Neuropathology 2000;20:273-82.

80. Jia J, Guan D, Zhu W, Alkayed NJ, Wang MM, Hua Z, et al. Estrogen inhibits Fas-mediated apoptosis in experimental stroke. Exp Neurol 2009;215:48-52.

81. Zhang X, Ha T, Lu C, Lam F, Liu L, Schweitzer J, et al. Poly (I: C) 
therapy decreases cerebral ischaemia/reperfusion injury via TLR3-mediated prevention of Fas/FADD interaction. J Cell Mol Med 2015;19:555-65.

82. Beer R, Franz G, Schöpf M, Reindl M, Zelger B, Schmutzhard E, et al. Expression of Fas and Fas ligand after experimental traumatic brain injury in the rat. J Cereb Blood Flow Metab 2000;20:669-77.

83. You Z, Savitz SI, Yang J, Degterev A, Yuan J, Cuny GD, et al. Necrostatin-1 reduces histopathology and improves functional outcome after controlled cortical impact in mice. J Cereb Blood Flow Metab 2008;28:1564-73.

84. Bermpohl D, You Z, Lo EH, Kim HH, Whalen MJ. TNF alpha and Fas mediate tissue damage and functional outcome after traumatic brain injury in mice. J Cereb Blood Flow Metab 2007;27:1806-18.

85. Khuman J, Meehan WP $3^{\text {rd }}$, Zhu X, Qiu J, Hoffmann U, Zhang J, et al. Tumor necrosis factor alpha and Fas receptor contribute to cognitive deficits independent of cell death after concussive traumatic brain injury in mice. J Cereb Blood Flow Metab 2011;31:778-89.

86. Lin $\mathrm{CH}$, Chen $\mathrm{M}$, Sun MC. Circulating apoptotic factors in patients with acute cerebral infarction. Clin Biochem 2010;43:761-3.

87. Cevik O, Adiguzel Z, Baykal AT, Somay G, Sener A. The apoptotic actions of platelets in acute ischemic stroke. Mol Biol Rep 2013;40:6721-7.

88. Pascotini ET, Flores AE, Kegler A, Gabbi P, Bochi GV, Algarve TD, et al. Apoptotic markers and DNA damage are related to late phase of stroke: Involvement of dyslipidemia and inflammation. Physiol Behav 2015;151:369-78.

89. Pan DS, Liu WG, Yang XF, Cao F. Inhibitory effect of progesterone on inflammatory factors after experimental traumatic brain injury. Biomed Environ Sci 2007;20:432-8.

90. Jin $\mathrm{W}$, Wang $\mathrm{H}$, Yan W, Xu L, Wang X, Zhao X, et al. Disruption of Nrf2 enhances upregulation of nuclear factor-kappaB activity, proinflammatory cytokines, and intercellular adhesion molecule-1 in the brain after traumatic brain injury. Mediators Inflamm 2008;2008:725174.

91. Allan SM, Rothwell NJ. Cytokines and acute neurodegeneration. Nat Rev Neurosci 2001;2:734-44.

92. Vanden Berghe T, Linkermann A, Jouan-Lanhouet S, Walczak H, Vandenabeele P. Regulated necrosis: The expanding network of non-apoptotic cell death pathways. Nat Rev Mol Cell Biol 2014;15:135-47.

93. Yang $\mathrm{Y}$, Zhou $\mathrm{H}$, Yang $\mathrm{Y}$, Li W, Zhou M, Zeng Z, et al. Lipopolysaccharide (LPS) regulates TLR4 signal transduction in nasopharynx epithelial cell line 5-8F via NFkappaB and MAPKs signaling pathways. Mol Immunol 2007;44:984-92.

94. Thompson WL, Van Eldik LJ. Inflammatory cytokines stimulate the chemokines CCL2/MCP-1 and CCL7/MCP-3 through NFkB and MAPK dependent pathways in rat astrocytes [corrected]. Brain Res 2009;1287:47-57.

95. Tao L, Chen X, Qin Z, Bian S. Could NF-kappaB and caspase-3 be markers for estimation of post-interval of human traumatic brain injury? Forensic Sci Int 2006;162:174-7.

96. Hang CH, Chen G, Shi JX, Zhang X, Li JS. Cortical expression of nuclear factor kappaB after human brain contusion. Brain Res 2006;1109:14-21.

97. Laird MD, Sukumari-Ramesh S, Swift AE, Meiler SE, Vender JR, Dhandapani KM. Curcumin attenuates cerebral edema following traumatic brain injury in mice: A possible role for aquaporin-4? J Neurochem 2010;113:637-48.

98. Katada R, Nishitani Y, Honmou O, Okazaki S, Houkin K, Matsumoto $\mathrm{H}$. Prior ethanol injection promotes brain edema after traumatic brain injury. J Neurotrauma 2009;26:2015-25.

99. Wang ZR, Li YX, Lei HY, Yang DQ, Wang LQ, Luo MY. Regulating effect of activated NF- $\mathrm{KB}$ on edema induced by traumatic brain injury of rats. Asian Pac J Trop Med 2016;9:274-7.

100. Jayakumar AR, Tong XY, Ruiz-Cordero R, Bregy A, Bethea JR, Bramlett $\mathrm{HM}$, et al. Activation of NF- $\mathrm{KB}$ mediates astrocyte swelling and brain edema in traumatic brain injury. J Neurotrauma 2014;31:1249-57.

101. Scaffidi C, Schmitz I, Zha J, Korsmeyer SJ, Krammer PH, Peter ME. Differential modulation of apoptosis sensitivity in CD95 type I and type II cells. J Biol Chem 1999;274:22532-8.

102. Scaffidi C, Fulda S, Srinivasan A, Friesen C, Li F, Tomaselli $\mathrm{KJ}$, et al. Two CD95 (APO-1/Fas) signaling pathways. EMBO J 1998;17:1675-87.

103. Li H, Zhu H, Xu CJ, Yuan J. Cleavage of BID by caspase 8 mediates the mitochondrial damage in the Fas pathway of apoptosis. Cell 1998;94:491-501.

104. Luo X, Budihardjo I, Zou H, Slaughter C, Wang X. Bid, a $\mathrm{Bcl} 2$ interacting protein, mediates cytochrome c release from mitochondria in response to activation of cell surface death receptors. Cell 1998;94:481-90.

105. Franz G, Beer R, Intemann D, Krajewski S, Reed JC, Engelhardt $K$, et al. Temporal and spatial profile of Bid cleavage after experimental traumatic brain injury. J Cereb Blood Flow Metab 2002;22:951-8.

106. Day RJ,Mason MJ, Thomas C, Poon WW, Rohn TT. Caspase-cleaved tau co-localizes with early tangle markers in the human vascular dementia brain. PLoS One 2015;10:e0132637.

107. Bramlett HM, Dietrich WD. Long-term consequences of traumatic brain injury: Current status of potential mechanisms of injury and neurological outcomes. J Neurotrauma 2015;32:1834-48.

108. Carvey PM, Hendey B, Monahan AJ. The blood-brain barrier in neurodegenerative disease: A rhetorical perspective. J Neurochem 2009;111:291-314.

109. Zhu SG, Sheng JG, Jones RA, Brewer MM, Zhou XQ, Mrak RE, et al. Increased interleukin-1beta converting enzyme expression and activity in Alzheimer disease. J Neuropathol Exp Neurol 1999;58:582-7.

110. Selznick LA, Holtzman DM, Han BH, Gökden M, Srinivasan AN, Johnson EM Jr., et al. In situ immunodetection of neuronal caspase-3 activation in Alzheimer disease. J Neuropathol Exp Neurol 1999;58:1020-6.

111. Matsui T, Ramasamy K, Ingelsson M, Fukumoto H, Conrad C, Frosch MP, et al. Coordinated expression of caspase 8, 3 and 7 mRNA in temporal cortex of Alzheimer disease: Relationship to formic acid extractable abeta42 levels. J Neuropathol Exp Neurol 2006;65:508-15.

112. Rohn TT, Rissman RA, Davis MC, Kim YE, Cotman CW, Head E. Caspase-9 activation and caspase cleavage of tau in the Alzheimer's disease brain. Neurobiol Dis 2002;11:341-54.

113. Guo H, Albrecht S, Bourdeau M, Petzke T, Bergeron C, LeBlanc AC. Active caspase-6 and caspase-6-cleaved tau in neuropil threads, neuritic plaques, and neurofibrillary tangles of Alzheimer's disease. Am J Pathol 2004;165:523-31.

114. Sheng JG, Mrak RE, Jones RA, Brewer MM, Zhou XQ, McGinness J, et al. Neuronal DNA damage correlates with overexpression of interleukin-1beta converting enzyme in APPV717F mice. Neurobiol Aging 2001;22:895-902.

115. Pozueta J, Lefort R, Ribe EM, Troy CM, Arancio O, Shelanski M. Caspase- 2 is required for dendritic spine and behavioural alterations in J20 APP transgenic mice. Nat Commun 2013;4:1939.

116. $\mathrm{Su} \mathrm{JH}$, Zhao M, Anderson AJ, Srinivasan A, Cotman CW. Activated caspase-3 expression in Alzheimer's and aged control brain: Correlation with Alzheimer pathology. Brain Res 2001;898:350-7.

117. Rohn TT, Head E, Nesse WH, Cotman CW, Cribbs DH. Activation of caspase- 8 in the Alzheimer's disease brain. Neurobiol Dis 2001;8:1006-16.

118. Abdul-Muneer PM, Schuetz H, Wang F, Skotak M, Jones J, Gorantla S, et al. Induction of oxidative and nitrosative damage leads to cerebrovascular inflammation in an animal model of mild traumatic brain injury induced by primary blast. Free Radic Biol Med 2013;60:282-91. 
119. Stone JR, Okonkwo DO, Singleton RH, Mutlu LK, Helm GA, Povlishock JT. Caspase-3-mediated cleavage of amyloid precursor protein and formation of amyloid Beta peptide in traumatic axonal injury. J Neurotrauma 2002;19:601-14.

120. Cotman CW, Poon WW, Rissman RA, Blurton-Jones M. The role of caspase cleavage of tau in Alzheimer disease neuropathology. J Neuropathol Exp Neurol 2005;64:104-12.

121. Rissman RA, Poon WW, Blurton-Jones M, Oddo S, Torp R, Vitek MP, et al. Caspase-cleavage of tau is an early event in Alzheimer disease tangle pathology. J Clin Invest 2004;114:121-30.

122. Gamblin TC, Chen F, Zambrano A, Abraha A, Lagalwar S, Guillozet AL, et al. Caspase cleavage of tau: Linking amyloid and neurofibrillary tangles in Alzheimer's disease. Proc Natl Acad Sci U S A 2003;100:10032-7.

123. Gendron TF, Petrucelli L. The role of tau in neurodegeneration. Mol Neurodegener 2009;4:13.

124. Faden AI, Loane DJ. Chronic neurodegeneration after traumatic brain injury: Alzheimer disease, chronic traumatic encephalopathy, or persistent neuroinflammation? Neurotherapeutics 2015;12:143-50.

125. Rohn TT. Caspase cleaved tau in Alzheimer's disease: A therapeutic target realized. Int J Neurol Neurother 2015;2:014.

126. Kanaan NM, Cox K, Alvarez VE, Stein TD, Poncil S, McKee AC. Characterization of early pathological tau conformations and phosphorylation in chronic traumatic encephalopathy. J Neuropathol Exp Neurol 2016;75:19-34.

127. Shahim P, Linemann T, Inekci D, Karsdal MA, Blennow K, Tegner Y, et al. Serum tau fragments predict return to play in concussed professional ice hockey players. J Neurotrauma 2016;33:1995-9.

128. Henriksen K, Byrjalsen I, Christiansen C, Karsdal MA. Relationship between serum levels of tau fragments and clinical progression of Alzheimer's disease. J Alzheimers Dis 2015;43:1331-41.

129. Brophy GM, Pineda JA, Papa L, Lewis SB, Valadka AB, Hannay $\mathrm{HJ}$, et al. alphaII-Spectrin breakdown product cerebrospinal fluid exposure metrics suggest differences in cellular injury mechanisms after severe traumatic brain injury. J Neurotrauma 2009;26:471-9.

130. Reeves TM, Greer JE, Vanderveer AS, Phillips LL. Proteolysis of submembrane cytoskeletal proteins ankyrin-G and aII-spectrin following diffuse brain injury: A role in white matter vulnerability at Nodes of Ranvier. Brain Pathol 2010;20:1055-68.

131. Cai Y, Zhu HX, Li JM, Luo XG, Patrylo PR, Rose GM, et al. Age-related intraneuronal elevation of aII-spectrin breakdown product SBDP120 in rodent forebrain accelerates in 3x Tg-AD mice. PLoS One 2012;7:e37599.

132. Rink A, Fung KM, Trojanowski JQ, Lee VM, Neugebauer E, McIntosh TK. Evidence of apoptotic cell death after experimental traumatic brain injury in the rat. Am J Pathol 1995;147:1575-83.

133. Luo C, Jiang J, Lu Y, Zhu C. Spatial and temporal profile of apoptosis following lateral fluid percussion brain injury. Chin J Traumatol 2002;5:24-7.

134. Li Y, Chopp M, Jiang N, Zaloga C. In situ detection of DNA fragmentation after focal cerebral ischemia in mice. Brain Res Mol Brain Res 1995;28:164-8.

135. Li M, Ona VO, Chen M, Kaul M, Tenneti L, Zhang X, et al. Functional role and therapeutic implications of neuronal caspase- 1 and -3 in a mouse model of traumatic spinal cord injury. Neuroscience 2000;99:333-42.

136. Liu XZ, Xu XM, Hu R, Du C, Zhang SX, McDonald JW, et al. Neuronal and glial apoptosis after traumatic spinal cord injury. J Neurosci 1997;17:5395-406.

137. Fink KB, Andrews LJ, Butler WE, Ona VO, Li M, Bogdanov M, et al. Reduction of post-traumatic brain injury and free radical production by inhibition of the caspase- 1 cascade. Neuroscience 1999;94:1213-8.

138. Yakovlev AG, Knoblach SM, Fan L, Fox GB, Goodnight R, Faden AI. Activation of CPP32-like caspases contributes to neuronal apoptosis and neurological dysfunction after traumatic brain injury. J Neurosci 1997;17:7415-24.

139. Friedlander RM, Gagliardini V, Hara H, Fink KB, Li W, MacDonald G, et al. Expression of a dominant negative mutant of interleukin- 1 beta converting enzyme in transgenic mice prevents neuronal cell death induced by trophic factor withdrawal and ischemic brain injury. J Exp Med 1997;185:933-40.

140. Friedlander RM, Yuan J. ICE, neuronal apoptosis and neurodegeneration. Cell Death Differ 1998;5:823-31.

141. Culmsee C, Landshamer S. Molecular insights into mechanisms of the cell death program: Role in the progression of neurodegenerative disorders. Curr Alzheimer Res 2006;3:269-83.

142. Enari M, Talanian RV, Wong WW, Nagata S. Sequential activation of ICE-like and CPP32-like proteases during Fas-mediated apoptosis. Nature 1996;380:723-6.

143. Rabuffetti M, Sciorati C, Tarozzo G, Clementi E, Manfredi AA, Beltramo M. Inhibition of caspase-1-like activity by Ac-Tyr-Val-Ala-Asp-chloromethyl ketone induces long-lasting neuroprotection in cerebral ischemia through apoptosis reduction and decrease of proinflammatory cytokines. J Neurosci 2000;20:4398-404.

144. Kang SJ, Wang S, Hara H, Peterson EP, Namura S, Amin-Hanjani S, et al. Dual role of caspase-11 in mediating activation of caspase-1 and caspase- 3 under pathological conditions. J Cell Biol 2000;149:613-22.

145. Benchoua A, Guégan C, Couriaud C, Hosseini H, Sampaïo N, Morin D, et al. Specific caspase pathways are activated in the two stages of cerebral infarction. J Neurosci 2001;21:7127-34.

146. Beer R, Franz G, Srinivasan A, Hayes RL, Pike BR, Newcomb JK, et al. Temporal profile and cell subtype distribution of activated caspase-3 following experimental traumatic brain injury. J Neurochem 2000;75:1264-73.

147. Beer R, Franz G, Krajewski S, Pike BR, Hayes RL, Reed JC, et al. Temporal and spatial profile of caspase 8 expression and proteolysis after experimental traumatic brain injury. J Neurochem 2001;78:862-73.

148. Zhang X, Alber S, Watkins SC, Kochanek PM, Marion DW, Graham SH, et al. Proteolysis consistent with activation of caspase-7 after severe traumatic brain injury in humans. J Neurotrauma 2006;23:1583-90.

149. Larner SF, Hayes RL, McKinsey DM, Pike BR, Wang KK. Increased expression and processing of caspase-12 after traumatic brain injury in rats. J Neurochem 2004;88:78-90.

150. Larner SF, McKinsey DM, Hayes RL, W Wang KK. Caspase 7: Increased expression and activation after traumatic brain injury in rats. J Neurochem 2005;94:97-108.

151. Qiu J, Whalen MJ, Lowenstein P, Fiskum G, Fahy B, Darwish R, et al. Upregulation of the Fas receptor death-inducing signaling complex after traumatic brain injury in mice and humans. J Neurosci 2002;22:3504-11.

152. Darwish RS, Amiridze NS. Detectable levels of cytochrome $C$ and activated caspase-9 in cerebrospinal fluid after human traumatic brain injury. Neurocrit Care 2010;12:337-41.

153. Clark RS, Kochanek PM, Watkins SC, Chen M, Dixon CE, Seidberg NA, et al. Caspase-3 mediated neuronal death after traumatic brain injury in rats. J Neurochem 2000;74:740-53.

154. Alessandri B, Nishioka T, Heimann A, Bullock RM, Kempski O. Caspase-dependent cell death involved in brain damage after acute subdural hematoma in rats. Brain Res 2006;1111:196-202.

155. Martinou JC, Dubois-Dauphin M, Staple JK, Rodriguez I, Frankowski H, Missotten M, et al. Overexpression of BCL-2 in transgenic mice protects neurons from naturally occurring cell death and experimental ischemia. Neuron 1994;13:1017-30.

156. Plesnila N, Zinkel S, Le DA, Amin-Hanjani S, Wu Y, Qiu J, et al. BID mediates neuronal cell death after oxygen/glucose deprivation and focal cerebral ischemia. Proc Natl Acad Sci U S A 2001;98:15318-23. 
157. Mitsios N, Gaffney J, Krupinski J, Mathias R, Wang Q, Hayward S, et al. Expression of signaling molecules associated with apoptosis in human ischemic stroke tissue. Cell Biochem Biophys 2007;47:73-86.

158. Clark RS, Kochanek PM, Chen M, Watkins SC, Marion DW, Chen J, et al. Increases in Bcl-2 and cleavage of caspase- 1 and caspase- 3 in human brain after head injury. FASEB J 1999;13:813-21.

159. Nathoo N, Narotam PK, Agrawal DK, Connolly CA, van Dellen JR, Barnett GH, et al. Influence of apoptosis on neurological outcome following traumatic cerebral contusion. J Neurosurg 2004;101:233-40.

160. Clark RS, Kochanek PM, Adelson PD, Bell MJ, Carcillo JA, Chen $\mathrm{M}$, et al. Increases in bcl-2 protein in cerebrospinal fluid and evidence for programmed cell death in infants and children after severe traumatic brain injury. J Pediatr 2000;137:197-204.

161. Au AK, Aneja RK, Bell MJ, Bayir H, Feldman K, Adelson PD, et al. Cerebrospinal fluid levels of high-mobility group box 1 and cytochrome $C$ predict outcome after pediatric traumatic brain injury. J Neurotrauma 2012;29:2013-21.

162. Rodhe J, Burguillos MA, de Pablos RM, Kavanagh E, Persson A, Englund E, et al. Spatio-temporal activation of caspase- 8 in myeloid cells upon ischemic stroke. Acta Neuropathol Commun 2016;4:92.

163. Wang G, Zhang J, Hu X, Zhang L, Mao L, Jiang X, et al. Microglia/ macrophage polarization dynamics in white matter after traumatic brain injury. J Cereb Blood Flow Metab 2013;33:1864-74.

164. Pettigrew LC, Kindy MS, Scheff S, Springer JE, Kryscio RJ, Li Y, et al. Focal cerebral ischemia in the TNFalpha-transgenic rat. J Neuroinflammation 2008;5:47.

165. Lei B, Dawson HN, Roulhac-Wilson B, Wang H, Laskowitz DT, James ML. Tumor necrosis factor a antagonism improves neurological recovery in murine intracerebral hemorrhage. J Neuroinflammation 2013;10:103.

166. Hutchison JS, Derrane RE, Johnston DL, Gendron N, Barnes D, Fliss $\mathrm{H}$, et al. Neuronal apoptosis inhibitory protein expression after traumatic brain injury in the mouse. J Neurotrauma 2001;18:1333-47.

167. Raghupathi R, Graham DI, McIntosh TK. Apoptosis after traumatic brain injury. J Neurotrauma 2000;17:927-38.

168. Wong J, Hoe NW, Zhiwei F, Ng I. Apoptosis and traumatic brain injury. Neurocrit Care 2005;3:177-82.

169. Zhang X, Chen Y, Jenkins LW, Kochanek PM, Clark RS. Bench-to-bedside review: Apoptosis/programmed cell death triggered by traumatic brain injury. Crit Care 2005;9:66-75.

170. Matsuda S, Umeda M, Kato H, Araki T. Glial damage after transient focal cerebral ischemia in rats. J Mol Neurosci 2009;38:220-6.

171. Love S, Barber R, Wilcock GK. Neuronal death in brain infarcts in man. Neuropathol Appl Neurobiol 2000;26:55-66.

172. Love S, Barber R, Srinivasan A, Wilcock GK. Activation of caspase-3 in permanent and transient brain ischaemia in man. Neuroreport 2000;11:2495-9.

173. Flygt J, Djupsjö A, Lenne F, Marklund N. Myelin loss and oligodendrocyte pathology in white matter tracts following traumatic brain injury in the rat. Eur J Neurosci 2013;38:2153-65.

174. Lotocki G, de Rivero Vaccari JP, Alonso O, Molano JS, Nixon R, Safavi $\mathrm{P}$, et al. Oligodendrocyte vulnerability following traumatic brain injury in rats. Neurosci Lett 2011;499:143-8.

175. Lotocki G, de Rivero Vaccari J, Alonso O, Molano JS, Nixon R, Dietrich WD, et al. Oligodendrocyte vulnerability following traumatic brain injury in rats: Effect of moderate hypothermia. Ther Hypothermia Temp Manag 2011;1:43-51.

176. Broughton BR, Reutens DC, Sobey CG. Apoptotic mechanisms after cerebral ischemia. Stroke 2009;40:e331-9.

177. Loddick SA, MacKenzie A, Rothwell NJ. An ICE inhibitor, $\mathrm{z}-\mathrm{VAD}$-DCB attenuates ischaemic brain damage in the rat. Neuroreport 1996;7:1465-8.
178. Hara H, Friedlander RM, Gagliardini V, Ayata C, Fink K, Huang Z, et al. Inhibition of interleukin 1beta converting enzyme family proteases reduces ischemic and excitotoxic neuronal damage. Proc Natl Acad Sci U S A 1997;94:2007-12.

179. Huang FP, Wang ZQ, Wu DC, Schielke GP, Sun Y, Yang GY. Early NFkappaB activation is inhibited during focal cerebral ischemia in interleukin-1beta-converting enzyme deficient mice. J Neurosci Res 2003;73:698-707.

180. Qi JP, Wu AP, Wang DS, Wang LF, Li SX, Xu FL. Correlation between neuronal injury and Caspase- 3 after focal ischemia in human hippocampus. Chin Med J (Engl) 2004;117:1507-12.

181. Rosell A, Cuadrado E, Alvarez-Sabín J, Hernández-Guillamon M, Delgado P, Penalba A, et al. Caspase-3 is related to infarct growth after human ischemic stroke. Neurosci Lett 2008;430:1-6.

182. Montaner J, Perea-Gainza M, Delgado P, Ribó M, Chacón P, Rosell A, et al. Etiologic diagnosis of ischemic stroke subtypes with plasma biomarkers. Stroke 2008;39:2280-7.

183. Montaner J, Mendioroz M, Ribó M, Delgado P, Quintana M, Penalba A, et al. A panel of biomarkers including caspase- 3 and D-dimer may differentiate acute stroke from stroke-mimicking conditions in the emergency department. J Intern Med 2011;270:166-74.

184. Inekci D, Linemann T, Ripova D, Henriksen K, Bartos A. Validation of a Caspase-3 generated tau fragment as a serum biomarker of brain damage due to stroke: Implications for Alzheimer's disease. Alzheimers Dement 2014;10:P654.

185. Rami A, Sims J, Botez G, Winckler J. Spatial resolution of phospholipid scramblase 1 (PLSCR1), caspase-3 activation and DNA-fragmentation in the human hippocampus after cerebral ischemia. Neurochem Int 2003;43:79-87.

186. Rossiter JP, Anderson LL, Yang F, Cole GM. Caspase-3 activation and caspase-like proteolytic activity in human perinatal hypoxic-ischemic brain injury. Acta Neuropathol 2002;103:66-73.

187. Takizawa Y, Takashima S, Itoh M. A histopathological study of premature and mature infants with pontosubicular neuron necrosis: Neuronal cell death in perinatal brain damage. Brain Res 2006;1095:200-6.

188. Askalan R, Deveber G,HoM,MaJ,Hawkins C. Astrocytic-inducible nitric oxide synthase in the ischemic developing human brain. Pediatr Res 2006;60:687-92.

189. Jain P, Spaeder MC, Donofrio MT, Sinha P, Jonas RA, Levy RJ. Detection of alpha II-spectrin breakdown products in the serum of neonates with congenital heart disease*. Pediatr Crit Care Med 2014;15:229-35.

190. Gu SJ, Lu M, Xuan HF, Chen XZ, Dong WF, Yan XF, et al. Predictive value of serum caspase-cleaved cytokeratin-18 concentrations after acute intracerebral hemorrhage. Clin Chim Acta 2016;452:124-8.

191. Zhang D, Yan H, Hu Y, Zhuang Z, Yu Z, Hang C. Increased expression of NLRP3 inflammasome in wall of ruptured and unruptured human cerebral aneurysms: Preliminary results. J Stroke Cerebrovasc Dis 2015;24:972-9.

192. Wang J, Wang JF, Hu XM. Caspase-3 in serum predicts outcome after aneurysmal subarachnoid hemorrhage. Clin Chim Acta 2016;460:196-202.

193. Yuan ZG, Wang JL, Jin GL, Yu XB, Li JQ, Qiu TL, et al. Serum caspase-cleaved cytokeratin-18 levels and outcomes after aneurysmal subarachnoid hemorrhage. J Neurol Sci 2015;359:298-304.

194. Lewis SB, Velat GJ, Miralia L, Papa L, Aikman JM, Wolper RA, et al. Alpha-II spectrin breakdown products in aneurysmal subarachnoid hemorrhage: A novel biomarker of proteolytic injury. J Neurosurg 2007;107:792-6.

195. Dressler J, Hanisch U, Kuhlisch E, Geiger KD. Neuronal and glial apoptosis in human traumatic brain injury. Int J Legal Med 2007;121:365-75.

196. Staffa K, Ondruschka B, Franke H, Dreßler J. Cerebellar 
gene expression following human traumatic brain injury. J Neurotrauma 2012;29:2716-21.

197. Härter L, Keel M, Hentze H, Leist M, Ertel W. Caspase-3 activity is present in cerebrospinal fluid from patients with traumatic brain injury. J Neuroimmunol 2001;121:76-8.

198. Lorente L, Martín MM, Argueso M, Ramos L, Solé-Violán J, Riaño-Ruiz M, et al. Serum caspase-3 levels and mortality are associated in patients with severe traumatic brain injury. BMC Neurol 2015;15:228.

199. Lorente L, Martín MM, González-Rivero AF, Argueso M, Ramos L, Solé-Violán J, et al. Serum levels of caspase-cleaved cytokeratin-18 in patients with severe traumatic brain injury are associated with mortality: A pilot study. PLoS One 2015;10:e0121739.

200. Farkas O, Polgár B, Szekeres-Barthó J, Dóczi T, Povlishock JT, Büki A. Spectrin breakdown products in the cerebrospinal fluid in severe head injury - Preliminary observations. Acta Neurochir (Wien) 2005;147:855-61.

201. Pineda JA, Lewis SB, Valadka AB, Papa L, Hannay HJ, Heaton SC, et al. Clinical significance of alphaII-spectrin breakdown products in cerebrospinal fluid after severe traumatic brain injury. J Neurotrauma 2007;24:354-66.

202. MondelloS, Robicsek SA, Gabrielli A, Brophy GM, Papa L, Tepas J, et al. aII-spectrin breakdown products (SBDPs): Diagnosis and outcome in severe traumatic brain injury patients. J Neurotrauma 2010;27:1203-13.

203. Glushakova O, Glushakov A, Hayes R. Finding effective biomarkers for pediatric traumatic brain injury. Brain Circ 2016;2:129-32.

204. Glushakova OY, Glushakov AV, Miller ER, Valadka AB, Hayes RL. Biomarkers for acute diagnosis and management of stroke in Neurointensive Care Units. Brain Circ 2016;2:28.

205. Knoblach SM, Nikolaeva M, Huang X, Fan L, Krajewski S, Reed JC, et al. Multiple caspases are activated after traumatic brain injury: Evidence for involvement in functional outcome. J Neurotrauma 2002;19:1155-70.

206. Ji W, Liu H, Liu C, Shao L, Liu Y, Fan S, et al. Up-regulation of $\mathrm{MCM} 3$ relates to neuronal apoptosis after traumatic brain injury in adult rats. Cell Mol Neurobiol 2017;37:683-93.

207. Nakajima W, Ishida A, Lange MS, Gabrielson KL, Wilson MA, Martin LJ, et al. Apoptosis has a prolonged role in the neurodegeneration after hypoxic ischemia in the newborn rat. J Neurosci 2000;20:7994-8004.

208. Han BH, DeMattos RB, Dugan LL, Kim-Han JS, Brendza RP, Fryer JD, et al. Clusterin contributes to caspase-3-independent brain injury following neonatal hypoxia-ischemia. Nat Med 2001;7:338-43.

209. Han BH, Xu D, Choi J, Han Y, Xanthoudakis S, Roy S, et al. Selective, reversible caspase-3 inhibitor is neuroprotective and reveals distinct pathways of cell death after neonatal hypoxic-ischemic brain injury. J Biol Chem 2002;277:30128-36.

210. Arvin KL, Han BH, Du Y, Lin SZ, Paul SM, Holtzman DM. Minocycline markedly protects the neonatal brain against hypoxic-ischemic injury. Ann Neurol 2002;52:54-61.

211. Manabat C, Han BH, Wendland M, Derugin N, Fox CK, Choi J, et al. Reperfusion differentially induces caspase- 3 activation in ischemic core and penumbra after stroke in immature brain. Stroke 2003;34:207-13.

212. Pulera MR, Adams LM, Liu H, Santos DG, Nishimura RN, Yang $\mathrm{F}$, et al. Apoptosis in a neonatal rat model of cerebral hypoxia-ischemia. Stroke 1998;29:2622-30.

213. Wei L, Han BH, Li Y, Keogh CL, Holtzman DM, Yu SP. Cell death mechanism and protective effect of erythropoietin after focal ischemia in the whisker-barrel cortex of neonatal rats. J Pharmacol Exp Ther 2006;317:109-16.

214. Zhu C, Wang X, Hagberg H, Blomgren K. Correlation between caspase- 3 activation and three different markers of DNA damage in neonatal cerebral hypoxia-ischemia. J Neurochem 2000;75:819-29.

215. West T, Atzeva M, Holtzman DM. Caspase-3 deficiency during development increases vulnerability to hypoxic-ischemic injury through caspase-3-independent pathways. Neurobiol Dis 2006;22:523-37.

216. Le DA, Wu Y, Huang Z, Matsushita K, Plesnila N, Augustinack JC, et al. Caspase activation and neuroprotection in caspase-3-deficient mice after in vivo cerebral ischemia and in vitro oxygen glucose deprivation. Proc Natl Acad Sci U S A 2002;99:15188-93.

217. Caulín C, Salvesen GS, Oshima RG. Caspase cleavage of keratin 18 and reorganization of intermediate filaments during epithelial cell apoptosis. J Cell Biol 1997;138:1379-94.

218. Dash PK, Zhao J, Hergenroeder G, Moore AN. Biomarkers for the diagnosis, prognosis, and evaluation of treatment efficacy for traumatic brain injury. Neurotherapeutics 2010;7:100-14.

219. Zhang Z, Larner SF, Liu MC, Zheng W, Hayes RL, Wang KK. Multiple alphaII-spectrin breakdown products distinguish calpain and caspase dominated necrotic and apoptotic cell death pathways. Apoptosis 2009;14:1289-98.

220. Witek MA, Fung LW. Quantitative studies of caspase-3 catalyzed aII-spectrin breakdown. Brain Res 2013;1533:1-15.

221. Wang KK. Calpain and caspase: Can you tell the difference? Trends Neurosci 2000;23:20-6.

222. Kobeissy FH, Liu MC, Yang Z, Zhang Z, Zheng W, Glushakova O, et al. Degradation of $B I I-$ spectrin protein by calpain-2 and Caspase-3 under neurotoxic and traumatic brain injury conditions. Mol Neurobiol 2015;52:696-709.

223. Ren C, Zoltewicz S, Guingab-Cagmat J, Anagli J, Gao M, Hafeez A, et al. Different expression of ubiquitin C-terminal hydrolase-L1 and aII-spectrin in ischemic and hemorrhagic stroke: Potential biomarkers in diagnosis. Brain Res 2013;1540:84-91.

224. Pike BR, Flint J, Dave JR, Lu XC, Wang KK, Tortella FC, et al. Accumulation of calpain and caspase- 3 proteolytic fragments of brain-derived alphaII-spectrin in cerebral spinal fluid after middle cerebral artery occlusion in rats. J Cereb Blood Flow Metab 2004;24:98-106.

225. Zhang C, Siman R, Xu YA, Mills AM, Frederick JR, Neumar RW. Comparison of calpain and caspase activities in the adult rat brain after transient forebrain ischemia. Neurobiol Dis 2002;10:289-05.

226. Yokobori S, Hosein K, Burks S, Sharma I, Gajavelli S, Bullock R. Biomarkers for the clinical differential diagnosis in traumatic brain injury - A systematic review. CNS Neurosci Ther 2013;19:556-65.

227. Siman R, Giovannone N, Toraskar N, Frangos S, Stein SC, Levine JM, et al. Evidence that a panel of neurodegeneration biomarkers predicts vasospasm, infarction, and outcome in aneurysmal subarachnoid hemorrhage. PLoS One 2011;6:e28938.

228. Avila J, Lucas JJ, Perez M, Hernandez F. Role of tau protein in both physiological and pathological conditions. Physiol Rev 2004;84:361-84.

229. Grundke-Iqbal I, Iqbal K, Tung YC, Quinlan M, Wisniewski HM, Binder LI. Abnormal phosphorylation of the microtubule-associated protein tau (tau) in Alzheimer cytoskeletal pathology. Proc Natl Acad Sci U S A 1986;83:4913-7.

230. Grundke-Iqbal I, Iqbal K, Quinlan M, Tung YC, Zaidi MS, Wisniewski HM. Microtubule-associated protein tau. A component of Alzheimer paired helical filaments. J Biol Chem 1986;261:6084-9.

231. Andreasen N, Minthon L, Clarberg A, Davidsson P, Gottfries J, Vanmechelen E, et al. Sensitivity, specificity, and stability of CSF-tau in $\mathrm{AD}$ in a community-based patient sample. Neurology 1999;53:1488-94.

232. Hampel H, Blennow K, Shaw LM, Hoessler YC, Zetterberg H, Trojanowski JQ. Total and phosphorylated tau protein as biological 
markers of Alzheimer's disease. Exp Gerontol 2010;45:30-40.

233. Hesse C, Rosengren L, Vanmechelen E, Vanderstichele H, Jensen C, Davidsson P, et al. Cerebrospinal fluid markers for Alzheimer's disease evaluated after acute ischemic stroke. J Alzheimers Dis 2000;2:199-206.

234. Hesse C, Rosengren L, Andreasen N, Davidsson P, Vanderstichele H, Vanmechelen E, et al. Transient increase in total tau but not phospho-tau in human cerebrospinal fluid after acute stroke. Neurosci Lett 2001;297:187-90.

235. Bielewicz J, Kurzepa J, Czekajska-Chehab E, Stelmasiak Z, Bartosik-Psujek H. Does serum tau protein predict the outcome of patients with ischemic stroke? J Mol Neurosci 2011;43:241-5.

236. Franz G, Beer R, Kampfl A, Engelhardt K, Schmutzhard E, Ulmer $\mathrm{H}$, et al. Amyloid beta 1-42 and tau in cerebrospinal fluid after severe traumatic brain injury. Neurology 2003;60:1457-61.

237. Ost M, Nylén K, Csajbok L, Ohrfelt AO, Tullberg M, Wikkelsö C, et al. Initial CSF total tau correlates with 1-year outcome in patients with traumatic brain injury. Neurology 2006;67:1600-4.

238. Bulut M, Koksal O, Dogan S, Bolca N, Ozguc H, Korfali E, et al. Tau protein as a serum marker of brain damage in mild traumatic brain injury: Preliminary results. Adv Ther 2006;23:12-22.

239. Kavalci C, Pekdemir M, Durukan P, Ilhan N, Yildiz M, Serhatlioglu $\mathrm{S}$, et al. The value of serum tau protein for the diagnosis of intracranial injury in minor head trauma. Am J Emerg
Med 2007;25:391-5.

240. Liliang PC, Liang CL, Weng HC, Lu K, Wang KW, Chen HJ, et al. Tau proteins in serum predict outcome after severe traumatic brain injury. J Surg Res 2010;160:302-7.

241. Hjalmarsson C, Bjerke M, Andersson B, Blennow K, Zetterberg H, Aberg ND, et al. Neuronal and glia-related biomarkers in cerebrospinal fluid of patients with acute ischemic stroke. J Cent Nerv Syst Dis 2014;6:51-8.

242. Wunderlich MT, Lins H, Skalej M, Wallesch CW, Goertler M. Neuron-specific enolase and tau protein as neurobiochemical markers of neuronal damage are related to early clinical course and long-term outcome in acute ischemic stroke. Clin Neurol Neurosurg 2006;108:558-63.

243. Hu HT, Xiao F, Yan YQ, Wen SQ, Zhang L. The prognostic value of serum tau in patients with intracerebral hemorrhage. Clin Biochem 2012;45:1320-4.

244. Yang Z, Lin F, Robertson CS, Wang KK. Dual vulnerability of TDP-43 to calpain and caspase-3 proteolysis after neurotoxic conditions and traumatic brain injury. J Cereb Blood Flow Metab 2014;34:1444-52.

245. Yang X, Yang S, Zhang J, Xue L, Hu Z. Role of Caspase 3 in neuronal apoptosis after acute brain injury. Chin J Traumatol 2002;5:250-3. 